\title{
Afghanistan: Building a State to Keep the Peace
}

Afsah, Ebrahim; Guhr, Alexandra Hilal

Published in:

Max Planck Yearbook of United Nations Law

Publication date:

2005

Document version

Publisher's PDF, also known as Version of record

Citation for published version (APA):

Afsah, E., \& Guhr, A. H. (2005). Afghanistan: Building a State to Keep the Peace. Max Planck Yearbook of United Nations Law, 9, 373-456. 


\section{Afghanistan: Building a State to Keep the Peace}

Ebrabim Afsab/ Alexandra Hilal Gubr

I. Introduction

1. Common Misperceptions

a. Did the Conflict destroy the State?

b. Was it an Ethnic Conflict?

c. Was the UN too Dominant?

2. Unusual Characteristics
a. UN not in the Driver's Seat
b. Not a Settlement, but a Process
c. No Transitional Justice Component
d. Simultaneous Arming and (half-hearted) Demobilization

II. Background

1. History of the State

2. Civil Society

3. Political Society

III. The Path to the Bonn Agreement

1. Previous UN Involvement

2. Consequences of the "Brahimi Report"

3. Present UN involvement and the Bonn Agreement
a. Events Leading to Bonn
b. The Negotiations in Bonn
c. UNAMA's Mandate

IV. Instruments of the Bonn Process

1. Interim Authority and Emergency Loya Jirga

2. Constitutional Process
a. The Drafting Process
b. The Constitutional Loya Jirga
c. The Constitution

3. Elections
a. Presidential Elections
b. Parliamentary Elections 
V. Further Obstacles to the Reconstruction Process

1. Financial Commitments

2. Security and Narcotics

3. The Afghan Independent Human Rights Commission and Transitional Justice

4. Disarmament, Demobilization and Reintegration (DDR)

a. Conceptual Issues

b. DDR in the Afghan Context

c. International Support for DDR

d. Critique of the International Effort

VI. Conclusion

\section{Introduction}

The American decision to remove the Taliban government from power suddenly opened a window of opportunity for the resolution of the long Afghan conflict. ${ }^{1}$ The resulting United Nations brokered settlement and the subsequent reconstruction process remained in many respects a sui generis mission. Partly this is due to the peculiar nature of the Afghan conflict, which required a particularly careful, non-intrusive approach. Also of importance is, however, that the peace process has run parallel - and often been subservient - to the ongoing American-led "war on terror".

These two factors, namely Afghan sensibilities and American military necessities, have affected the peace process in numerous ways and required a number of carefully orchestrated compromises. The concessions that have been necessary in this respect have been forcefully decried by both domestic and international non-governmental organizations and the media, focusing in particular on the continued heavy involvement of former warlords in the government, the lack of security, and the international unwillingness to extent robust peace-keeping beyond Kabul. ${ }^{2}$ While much of this criticism is logically consistent, and

1 The period prior to the American intervention is well described in A. Rashid, Taliban: Islam, Oil, and the New Great Game in Central Asia, 2000, Chapter 1.

2 The authorization for an expansion of the ISAF mandate to allow a deployment of ISAF troops outside of Kabul was accorded through S/RES/1510 (2003) of 13 October 2003. Until February 2005 a total of five Provincial Reconstruction Teams (PRTs) had been deployed to cities in the North. An expansion to the West is planned, but until now wide parts of the country are still insecure. 
normatively plausible, it does not take into account the existing political and military realities that heavily constrain the limits within which a political settlement can be pursued.

The main contribution of the United Nations and its chief representative Brahimi in the Bonn process was the brokering of what can be argued to constitute a consensus of the elite. By including power holders prominently in the process, and by letting them partake in the "spoils of peace", strong incentives were created against a continuation of factional violence. We do not argue here that the role of the international community and the United Nations has been without reproach. But all criticism must take into account the structure of constraint which severely limits what can realistically be expected. ${ }^{3}$

We argue in this paper that given the limitations of the historical context and the realities of power and interests - both within the Coalition and the militias - progress could only be achieved if these forces were brought into the process, not by working against the realities on the ground.

\section{Common Misperceptions}

Much commentary about Afghanistan is based on a set of assumptions that on closer examination does not hold up to scrutiny. These assumptions centre on the assessment of the impact of war and domestic conflict on the state and on the characterization of the conflict as an ethnic one. The nature of the internationally brokered settlement process is often also misunderstood and will be addressed further on in this paper.

\section{a. Did the Conflict destroy the State?}

Many reports, especially emanating from the NGO community, begin by restating the destruction of state and society during 23 years of war. ${ }^{4}$ While this is in itself an accurate description, it is often implied, sometimes explicitly, sometimes implicitly, that the main task is one of re-

3 J.L. Gaddis, "International Relations Theory and the End of the Cold War”, International Security 19 (1992/93), 5 et seq. fn. 142.

4 "Mehr als 20 Jahre Bürgerkrieg haben in Afghanistan nicht nur die Infrastruktur des Landes, sondern auch sämtliche öffentlichen und sozialen Institutionen zerstört," M. Klinger, Bericht Gutachter Einsatz Afghanistan, GTZ, 2002, 1. 
construction of state institutions. More accurate, however, seems the notion that even before the war the Afghan state was exceedingly weak and not properly equipped for the administration of the country and the delivery of services to its citizens. Using cautious diplomatic language, this point is stressed in a recent UN study with regard to the justice sector and applies mutatis mutandis to the entire Afghan state structure:

"It is frequently stated that the formal justice system has been 'totally destroyed' by the 23 years of civil unrest and war. This is an imprecise perception/assessment of the situation. It does not consider the role and functioning of the existing mechanisms and practices; imprecise because the formal legal tradition and mechanisms are much less consolidated than usually presumed." 5

International assistance to the Afghan transitional process must therefore not "merely" aim at reconstructing governmental structures, but must start from the assumption that effective governance in the modern sense has never existed, even before the war. This not only makes the task a more formidable one, but also mandates a much more careful interaction with dispersed power holders. It is thus not the reconstruction of formerly existing state structures that we are faced with, but in some sense the initial act of creation of the political community that transcends pre-modern ethnic, linguistic, religious and geographic loyalties.

In this respect it is useful to distinguish between the external and internal aspects of statehood. While Afghanistan's external sovereignty has been largely ${ }^{6}$ uncontroversial since 1919 , internal state sovereignty

5 M. Toscano-Rivalta/ A. Drury, Securing Afghanistan's Future - Considerations on Criteria and Actions for Strengthening the Justice System - Proposal for a Long-term Strategic Framework, UNAMA, 2004, 4, emphasis added.

6 A Council of Ministers in accordance with article 100 of the 1990 Afghan Constitution (http://www.afghangovernment.com/Constitution1990.htm), led by the former President Burhunuddin Rabbani, was internationally recognized as the sole representative of the Afghan State. For details see R. Wolfrum/ C. Philipp, "The Status of the Taliban: Their Obligations and Rights under International Law", Max Planck UNYB 6 (2002), 559 et seq. $(567,576,577)$. The wisdom of the decision of the majority of the international community to withhold recognition from the de facto Taliban government, which referred to itself as the Islamic Emirate of Afghanistan and which held 90 per cent of the territory, has been much debated, especially given the fact that Rabbani did not even control the remaining ten per cent 
is an altogether different matter. At no point in Afghan history did the state provide the only, or even the main forum for the resolution of disputes. Even before armed conflict broke out in 1978 the standardization and formalization of the Afghan state had barely begun. Starting from Weber's influential definition of statehood as:

"a compulsory political association with continuous organisation whose administrative staff successfully upholds a claim to the monopoly of the legitimate use of force in enforcement of its orders in a given territorial unit",

it becomes debatable whether it is possible to say that an effective Afghan state has ever existed. ${ }^{8}$ The process set in motion by the fall of the Taliban regime concerns thus not merely the reconstruction of a formerly intact institutional structure, but the far more ambitious project of the initial negotiation of the original social contract that establishes the state as the locus of sovereignty.

As a caveat, institutional weakness should not be misunderstood as the complete absence of institutions. Many international commentators and experts charged with "capacity building" and "institutional development" "start from the assumption that all state structures had been "totally destroyed." They thus conclude that ready-made administra-

fully. It must be noted, however, that the failure of a new government of a state - in this case the Taliban - to secure recognition from other subjects of international law does not destroy the international personality of that state, nor does it absolve the respective state from observing treaty obligations entered into previously; see Sir R. Jennings/ Sir A. Watts (eds), Oppenheim's International Law, Vol. I, Peace, Introduction and Part 1, 9th edition, 1992, $\$ 44$. See also preambular para. 7 Bonn Agreement.

7 M. Weber, The Theory of Social and Economic Organisation, 1947, 154; see also F. Fukuyama, State-Building: Governance and World Order in the 21st Century, 2004, 6; D. Chagnollaud, Droit constitutionnel contemporain, 1999, 6.

8 On the link between statehood and the state's ability to use violence to enforce its decisions see also D. Held, Political Theory and the Modern State: Essays on State, Power and Democracy, 1989; A. Giddens, The Nation State and Violence, 1985.

9 Both terms have been used so indiscriminately that they have come to symbolize the vacuity of much UN terminology. While such technical terms describing a highly complex reality can make sense as abbreviations in an informed discourse among those who are aware of the complexities involved, they can quickly become meaningless placebos if they adorn project documents as substitutes for real action. 
tive blueprints from abroad can be imported and grafted onto the remnants of the existing state structures.

When dealing with international assistance given towards the reconstruction of the state, we thus need to have realistic expectations about what can be achieved, given the endemic weakness the state traditionally had. Nevertheless, any such assistance needs to take into account the local conditions and organizational habits that even these weak institutions were able to form.

\section{b. Was it an Ethnic Conflict?}

Afghanistan is a perplexingly diverse country with a large number of different ethnic groups separated by ethnicity, religion, language, and geography. There are at least four major ethnic groups (Pashtus, Tajiks, Hazaras, Usbeks), and countless smaller ones; in addition to the two major languages (Pashtun and Dari, a form of Persian) a bewildering array of other languages are spoken (Turkic languages, Arabic, Nuristani, Dravidian, etc.). ${ }^{10}$ While almost the entire population is Muslim, ${ }^{11}$ there are important divisions between the Sunni and Shi'ite branches. ${ }^{12}$

But while "a large number of Afghans feel bound by strong norms of reciprocity linking them to their ethnic fellows", ${ }^{13}$ and while in the absence of strong competing claims on their loyalties on behalf of the

10 E. Orywal (ed.), Die ethnischen Gruppen Afghanistans: Fallstudien zu Gruppenidentitäten und Intergruppenbeziehungen, 1986; P. Snoy, "Die ethnischen Gruppen”, in: P. Bucherer-Dietschi/ C. Jentsch (eds), Afghanistan Ländermonografie, 1986, 121 et seq.

11 There are small Buddhist, Hindu and Sikh minorities. The small erstwhile Jewish minority has left the country in its entirety and there are no significant numbers of Christians, the only church in the country being the one attached to the Italian embassy.

12 On the Shi'ite minority see inter alia K. Ferdinand, "Preliminary Notes on Hazara Culture - The Danish Scientific Mission to Afghanistan 1953-55", Historisk-filosofiske Meddelelser Udgivet af det Kongelige Danske Videnskabernes Selskab 37 (1959); H. Emadi, "The Hazaras and their Role in the Process of Political Transformation of Afghanistan”, Central Asian Survey 16 (1997), 363 et seq.; S.A. Mousavi, The Hazaras of Afghanistan - An Historical, Cultural, Economic and Political Study, 1998.

13 C. Johnson, et al., Afghanistan's Political and Constitutional Development, Overseas Development Institute, 2003, <www.odi.org.uk/hpg/ evaluations.html>. 
state ${ }^{14}$ these ethnic links have remained dominant, the characterization of the Afghan conflict as an ethnic one is misleading. To be sure, the main armed formations throughout the conflicts were organized along ethnic lines ${ }^{15}$ including some of the Soviet-backed communist government (General Dustum's Usbek militia for instance). Once the attempt to form a successor government in 1992 failed, these ethnically organized armed formations quickly turned onto each other.

But to infer from the existence of ethnic diversity and the observed fact of inter-ethnic violence that the conflict has been caused by ethnicity is a misleading oversimplification. ${ }^{16}$ More accurately, we can observe that a conflict that has political and social roots gradually became "ethnified" where ethnic identities were successfully used to mobilize material and manpower resources for a conflict waged for essentially opportunistic reasons. ${ }^{17}$

Alternative explanatory hypotheses focus on the destabilizing impact of the breakdown of security structures that suddenly pit individuals and groups against each other in a situation of anarchy. ${ }^{18}$ Without overarching authority, and in a situation of great uncertainty about each

14 A.D. Smith, The Ethnic Origins of Nations, 1986; R. Hardin, One for All: The Logic of Group Conflict, 1995.

15 C. Schetter, "Ethnizität als Ressource der Kriegsführung”, in: C. Schetter/ A. Wieland-Karimi (eds), Afghanistan in Geschichte und Gegenwart, 1999, 91 et seq.

16 C. Schetter, Ethnizität und ethnische Konflikte in Afghanistan, 2003.

17 C. Schetter, "Der Afghanistankrieg - Die Ethnisierung eines Konflikts", Internationales Asienforum 33 (2002), 15 et seq.; A. Wimmer, "Territoriale Schließung und die Politisierung des Ethnischen”, in: C. Honegger (ed.), Grenzenlose Gesellschaft? - Verhandlungen des 29. Kongresses der Deutschen Gesellschaft für Soziologie, 16. Kongresses der Österreichischen Gesellschaft für Soziologie und des 11. Kongresses der Schweizerischen Gesellschaft für Soziologie, 1999, 1200 et seq. UNDP, Afghanistan National Human Development Report 2004, Security with a Human Face: Challenges and Responsibilities, 2004, 100-102.

18 The term "anarchy" is used here as a technical term as defined in international relations theory. For a classical realist use of the term see K.A. Oye, "Explaining Cooperation Under Anarchy: Hypotheses and Strategies", World Politics 38 (1985); for a critical discussion see B. Buzan, et al., The Logic of Anarchy: Neorealism to Structural Realism, 1993; for a revisionist account see A. Wendt, "Anarchy is What States Make of It: The Social Construction of Power Politics”, International Organization 46 (1992), 391 et seq. 
others' intentions and readily available means to inflict serious damage, individuals and ethnic groups find themselves in a condition of pronounced security dilemma. ${ }^{19}$ In this interpretation the main motivation is not ethnic rivalries as such, but primarily defensive motives.

A related, but distinct hypothesis points out the proxy nature of many ethnic conflicts, i.e. its instrumentalization by external actors for self-interested reasons. ${ }^{20}$ A mutually reinforcing dynamic is created with the local war economy which provides tremendous personal opportunities for local military leaders who become strong agents in the perpetuation of the conflict, holding essentially their client communities hostage to their personal ambition and who have strong incentives to further inflame the conflict. ${ }^{21}$ An initially political conflict is thus turned into an ethnic one, not least due to external influence..$^{22}$ The involvement of external interests, both strategic and economic ${ }^{23}$, further sustains the conflict.

A close reading of the intricate and highly fluid constellations of the Afghan conflict, characterized by countless and perpetually shifting alliances, counter-alliances and betrayals, ${ }^{24}$ suggests that the root cause of the conflict cannot be seen in immutable ethnic rivalries but in personal

19 E. Melander, Anarchy Within: The Security Dilemma between Ethnic Groups in Emerging Anarchy, Department of Peace and Conflict Research Uppsala University, 1999.

20 S.J. Kaufman, “An 'International' Theory of Inter-Ethnic War”, Review of International Studies 22 (1996), 22 et seq.

21 S.J. Kaufman, "Spiraling to Ethnic War: Elites, Masses, and Moscow in Moldova's Civil War”, International Security 21 (1996), 108 et seq.

22 Schetter, see note 17 ,

23 United Nations Office on Drugs and Crime (UNODC), The Opium Economy in Afghanistan: An International Problem, 2003. While international involvement has been an important contributing factor to the conflict, we must be circumspect about some of the more outlandish claims emanating from the NGO community, this holds particularly true with regard to alleged Western interests in Central Asian hydrocarbon production. For an insightful discussion of the topic see Rashid, see note 1, although his conclusions about the inherent importance of Afghan access routes remain questionable. For a highly accusatory and ill-informed discussion of the same issue see G. Long/ D. Westcott, The United States's Oil Interests and the Reconstruction of Afghanistan, 2003, .

24 For an account of the conflict see Rashid, see note 1; B.R. Rubin, The Fragmentation of Afghanistan, 1995. 
ambition $^{25}$ and outside meddling. The opportunities offered by the war economy ${ }^{26}$ for some largely explain the incentive structures that drive civil wars, despite the unmitigated disaster that it spells for the many. ${ }^{27}$ We must not forget in this respect that in a situation of endemic conflict, many of the most dynamic and entrepreneurial sections of society will find no other outlet for their personal ambition than to avail themselves of the opportunities offered by the war economy. ${ }^{28}$

\section{c. Was the UN too Dominant?}

A too intrusive international effort would have been perceived as foreign domination, and could thus have triggered the kind of violent resistance that Afghans have shown throughout their history towards external interference. The respect shown by the international community towards the Afghan political process is in part a result of that history. It is therefore arguable that the United Nations had little choice but to stay consciously out of the limelight, whatever the conceptual lessons learned from previous missions.

Whether it was the sui generis character of Afghanistan or a deliberate strategic choice with wider implications for future missions, the

25 R.J.P.J. de Figueiredo/ B.R. Weingast, “The Rationality of Fear: Political Opportunism and Ethnic Conflict”, in: J. Snyder/ R. Jervis (eds), Civil War and the Security Dilemma, 1997.

26 B.R. Rubin, "The Political Economy of War and Peace in Afghanistan", World Development 28 (2000), 1789 et seq.; J. Goodhand, "From War Economy to Peace Economy? Reconstruction and State Building in Afghanistan", Journal of International Affairs 58 (2004), 155 et seq.; UNDP Human Development Report 2004, see note 17, 103-106.

27 For a theoretical treatment of the role of economic incentives in sustaining and prolonging conflict see J. Hirshleifer, The Dark Side of the Force: Economic Foundations of Conflict Theory, 2001.Olson's theory of collective action is likewise useful in this respect to account for the paradoxical fact that the "multitudes with an interest in peace" cannot prevail because "they have no lobby to match those of the 'special interests' that may on occasion have an interest in war.” M. Olson, The Logic of Collective Action: Public Goods and the Theory of Groups, 1971, 165.

28 A. Guistozzi, Respectable Warlords? The Transition from War of All against All to Peace Competition in Afghanistan, London School of Economics, Crisis States Research Seminar, 2003, who categorizes the various "career paths" and personal goals of some prominent commanders; quoted in Goodhand, see note 26, fn. 18. 
United Nations moved here from the more invasive approach that had characterized the previous missions and adopted a much more inclusive, consensual approach reminiscent of its missions of the early 1990 s. ${ }^{29}$ In the on-going UN mission in Afghanistan, emphasis has been placed on ensuring Afghan ownership of the reconstruction process, rather than imposing an international administration.

\section{Unusual Characteristics}

Compared to other peace-building and peace-keeping efforts by the international community, the Afghan peace process is characterized by a number of factors that are unusual in this context: the limited role played by the United Nations; the lack of a transitional justice component in the "Agreement on Provisional Arrangements in Afghanistan Pending the Re-establishment of Permanent Government Institutions" 30 of 5 December 2001, generally referred to as the Bonn Agreement; as well as the disabling factor of the ongoing military campaign against terrorist groups. In this context certain non-official groups continue to receive arms and military training, while simultaneously the political process previews a disarmament and reintegration of the militias.

\section{a. UN not in the Driver's Seat}

The United Nations has limited itself to playing a supporting role in Afghanistan, leaving visible leadership to Afghans. This so-called "light footprint" approach has been hailed as a major conceptual revolution in United Nation thinking, developed out of the perceived failures in Kosovo, East Timor and elsewhere. ${ }^{31}$ But whatever the conceptual les-

29 Such as UN operations in Namibia, El Salvador and Cambodia. For a cursory description and characterization of some of the UN post-conflict reconstruction operations since the 1990s, see J.S. Kreilkamp, "U.N. Postconflict Reconstruction”, N.Y.U. J. Int'l L. E Pol. 35 (2002 - 2003), 619 and seq.

30 Doc. S/2001/1154, <http://www.unhchr.ch/huricane/huricane.nsf/(Symbol) /MISC.01.5.En?OpenDocument $>$.

31 S. Chesterman, Justice Under International Administration: Kosovo, East Timor and Afghanistan, International Peace Academy, 2002, <www.ipacademy.org/PDF_Reports/JUSTICE_UNDER_INTL.pdf>; T. 
sons learned from previous UN missions, the peculiar Afghan situation, in particular the resistance to foreign domination that is borne out by this nation's history, made any more intrusive international role potentially highly problematic.

While the chronology and precise nature of the UN involvement in Afghanistan will be discussed under III., it shall suffice to note at this point that despite the seemingly prominent position, its role has been consciously relatively limited. Partly this is due to the perceived necessity of avoiding the impression of undue foreign interference, i.e. ensuring "Afghan ownership". The other reason has been the obvious importance of the American-led Coalition warfare that has run parallel to the peace building efforts of the United Nations. The normative and legal rules, as well as the strategic vision pursued by the United Nations and the United States, respectively, are by and large compatible, but nevertheless quite distinct. Their cooperation thus had to be managed "as porcupines do their love-making: very cautiously". ${ }^{32}$ The fact that their respective mandates are quite separate often blinds us to the relative discrepancy in terms of resources and manpower which is heavily tilted towards the United States.

\section{b. Not a Settlement, but a Process}

All post-conflict reconstruction scenarios involve a process in the sense that gradually institutions, norms, and physical infrastructure are being created. In all such situations armed groups that have been locked into violence for a very long time need to overcome their past ethnic, ideological, class and personal differences and learn to resolve their disputes without recourse to violence. There are many explanations why social relations unravel to the point that civil war breaks out, but whatever the origin of the violence, what is required at the start of the reconstruction

Pippard, East Timor and the Challenge of UN Transitional Administration, United Nations Association for Great Britain and Northern Ireland, $<$ http://www.una-uk.org/UN\&C/etimor.html> which has a good discussion of the impact the 2000 Brahimi Report has had on the approach taken in Afghanistan; S. Chesterman, "Walking Softly in Afghanistan: The Future of UN State-Building”, Survival 44 (2002), 37 et seq.; L. Brahimi, Peacekeeping: Five Years after the Report, Statement delivered on 1 March 2005 at the Institute of European Affairs, Dublin, <www.iiea.com/images/ managed/events_attachments/Brahimi010305.pdf $>$.

32 C. Bell, "Why an Expanded NATO must Include Russia”, in: T.G. Carpenter (ed.), The Future of NATO, 1995, 39. 
phase is the willingness to establish what Deutsch has termed a "security community", i.e. an arrangement "in which there is real assurance that the members of that community will not fight each other physically but will settle their disputes in some other way". ${ }^{33}$ Obviously, it will require time to move from a situation of high levels of inter-communal violence towards a real assurance that despite continuing conflicts over divergent interests, the conflicts will be resolved through the political process and violence will not be used. Building the necessary levels of trust between the former enemies out of necessity requires time, and in this respect every post-conflict situation is a process and not merely a settlement.

What distinguishes the Afghan situation from other post-conflict scenarios, however, is the absence of a formal agreement over the substantive content of the solution to the conflict: "Unlike some postwar agreements, the Bonn Accords set out a process, rather than a detailed settlement of major political issues." 34 The "classic" case of conflict resolution involves the signing of a peace treaty, provisional constitution, power sharing arrangement, or the like. The substantive content of such an agreement is "normally" negotiated over a period of months, if not years, and often comes at a point in time when all parties to the conflict have come to the conclusion that there is not much to be gained from continuing the armed struggle. ${ }^{35}$

Previous mediating efforts in Afghanistan, such as the Peshawar Accords, had actually followed that model of resolving the substantive issues and distributing power as part of the formal settlement. The situation in November 2001, however, was very different. Here the parties were brought together to negotiate a framework under extreme time pressure, while an external power had come in as an active and partisan participant in the conflict. Thus the Bonn negotiations resulted in very

33 K. Deutsch et al., Political Community and the North Atlantic Area, 1957, 5, emphasis added.

34 B.R. Rubin, Afghanistan's New Constitution, 2004, 2.

35 Luttwark makes this point in his controversial essay when he cautions against international interventions into ongoing domestic conflicts, arguing that sometimes the underlying conflict either needs to be resolved militarily, or that the parties must "grow tired" of war. Otherwise any international intervention just provides breathing space in which to recuperate and rearm, and thus prolongs the conflict. See E.N. Luttwak, "Give War a Chance", Foreign Aff. 4 (1999), 36 et seq. 
few substantive issues being settled, but rather concentrated on laying down the time-table and the overall framework in which to proceed. ${ }^{36}$

Given the combined pressures of time and a rapidly changing military reality, the group assembled in Bonn was of necessity less than completely representative of the various political and ethnic factions throughout Afghan society. However, Special Representative Brahimi repeatedly stressed "that no one would remember how unrepresentative the meeting had been if the participants managed to fashion a process that would lead to a legitimate and representative government". ${ }^{37}$ By leaving most substantive issues to be decided by the two subsequent, and much more inclusive, Loya Jirgas as well as laying down clear temporal limits on the authority conferred and stressing its transitional nature, the Bonn process managed to allay fears that it was meant to ossify a transitory power constellation.

\section{c. No Transitional Justice Component}

The term "transitional justice" refers to the processes and mechanisms associated with a society's attempts to come to terms with a legacy of large-scale past abuses, in order to ensure accountability, serve justice and achieve reconciliation. ${ }^{38}$ In the majority of post-conflict scenarios, the belligerent parties are brought together in a political process in the course of which they are able to agree to some form of legitimate process to lay to rest the allegations about past misconduct leveled against each other. ${ }^{39}$ In the Bonn process, however, of the four groups represented, only one, the Northern Alliance (Islamic United Front for the Salvation of Afghanistan), actually had armed forces on the ground, and these were engaged in combat not against the other participants but against the Taliban who were not represented at the negotiations. The quid pro quo that fuels the necessary dynamic of concessions and counter-concessions was thus absent in Bonn.

36 B.R. Rubin, "Transitional justice and human rights in Afghanistan - First Anthony Hyman Memorial Lecture at the School of Oriental and African Studies London”, International Affairs 79 (2003), 567 et seq. (570).

37 Rubin, see note $34,4$.

38 Report of the Secretary-General, The Rule of Law and Transitional Justice in Conflict and Post-conflict Societies, Doc. S/2004/616 of 23 August 2004, para. 4.

39 For example, see the case studies on Sierra Leone, East Timor and BosniaHerzegovina in this Volume. 
Furthermore, through their previous actions the Taliban had gradually placed themselves "beyond the pale". At least since the Taliban's refusal to comply with S/RES/1333 after the 11 September attacks, the international community no longer saw them as a legitimate partner in any negotiations. The Northern Alliance that was now allied with the Coalition in fighting them, was thus under no political obligation to agree to an investigation into its own past behavior.

Suggestions at Bonn about requiring the screening of new recruits into the national army and police to prevent candidates who had been guilty of war crimes came to no fruition because there was no judicial or similar process to determine who was ineligible, and, more importantly, because the ongoing policy of the Americans of arming Northern Alliance units to fight Taliban and al Qaeda created de facto forces without any such requirements. Similar suggestions about prohibiting a general amnesty for war crimes, or to prohibit the membership of commanders guilty of war crimes in the government were met with furious resistance. Similar resistance was very much in evidence during the Emergency Loya Jirga.

The lack of relevant regulations to deal with past abuses reflects the fact that some of the Afghan leaders ${ }^{40}$ who signed the Bonn Agreement are widely believed to have been responsible for war crimes and thus had no interest in including transitional justice regulations in the Bonn Agreement. This shortcoming was already anticipated by Brahimi in his report to the Security Council:

"The provisional institutions whose creation is suggested will not include every one who should be there and it may include some whose credentials many in Afghanistan may have doubts about. Please remember that what is hopefully to be achieved is the elusive peace ... the broad based interim administration is the beginning, not the end of the road". ${ }^{41}$

From this realist point of view, involving potential spoilers in the process rather than having them fighting against it may be well worth the price of compromising principles, at least for a transitional period. ${ }^{42}$

40 ICG, Asia Report No. 45, Afghanistan: Judicial Reform and Transitional Justice of 28 January 2003, 17.

41 L. Brahimi, "Briefing to the Security Council, Transcript from 13 November 2001", <http://www.un.org/News/dh/latest/afghan/brahimi-scbriefing.htm $>$, emphasis in the original.

42 Karzai's reluctant removal of some local commanders, most publicized that of Esmail Khan from his fiefdom in Herat, has been criticized as endanger- 
In the meantime, the Afghanistan Independent Human Rights Commission (AIHRC) has been charged with the responsibility of finding a way to account for the past. It conducted a national consultation in order to determine how a process of transitional justice could be structured in Afghanistan, and has made some proposals in accordance with the results of the survey. This will be discussed in more detail further on.

\section{d. Simultaneous Arming and (half-hearted) Demobilization}

Recovering from decades of armed conflict and managing the transition to a peaceful and stable post-war order is contingent on the successful disarmament and demobilization of armed groups and their reintegration into civilian life and the political process. The importance of disarmament, demobilization and reintegration (the so called DDR, as it is commonly abbreviated) is widely acknowledged, ${ }^{43}$ and it has become a "standard response to situations of post conflict". ${ }^{44}$

But despite the inherent importance of the concept and the vital role it is understood to play in the transition towards peace, ${ }^{45}$ the Bonn Agreement does not explicitly mention DDR but merely stipulates that:

"upon the transfer of power, all mujahedin, Afghan armed forces and armed groups in the country shall come under the command

ing the Bonn process. While this removal was motivated primarily by economic considerations (transferal of customs duties to the central government), the dangers outlined apply mutatis mutandis for such action motivated by considerations of transitional justice. See C. Schetter, "Ausweitung der Kampfzone”, Financial Times Deutschland of 17 September 2004, 38.

43 A. Özerdem, "DDR of former combatants in Afghanistan", Third World Quarterly 23 (2002), 961 and seq.; E. Gotab, Challenges of Peace Operations: Into the 21st Century: Concluding Report 1997-2002, 2002.

44 G. Wood, "Disarmament, Demobilisation and Reintegration: A Marriage of D's and R's?”, The Networker, March 2005, <http://www.bond. org.uk/networker/march05/ddr.htm>.

45 Report of the Secretary-General, Prevention of Armed Conflict, Doc. A/55/985-S/2001/574 of 7 June 2001, para. 23; Report of the SecretaryGeneral, The Role of United Nations Peacekeeping in Disarmament, Demobilization and Reintegration, Doc. S-2000/101 of 11 February 2000, para. 1; United Nations, Report of the Panel on United Nations Peace Operations, Doc. A/55/305-S/2000/809 of 21 August 2000, paras 7, 54. 
and control of the Interim Authority, and be reorganized according to the requirements of the new Afghan security and armed forces". 46

These groups referred to in the Bonn Agreement have been reorganized and formally recognized as the Afghan Military Forces (AMF). ${ }^{47}$ Many armed factions, however, are not classified as AMF units, and therefore do not fall under the DDR process. Furthermore, the American-led Coalition has relied extensively on local militias in the execution of its campaign against the Taliban and al Qaeda. These allied militias are generally not classified as AMF units, and have only very strained links to the central government and receive substantial military and financial resources from the Coalition.

The paradox of the UN and the central government trying to disband some factions, while the Coalition is actively arming others creates obvious problems for the transition process, which are described in somewhat greater detail later in this article.

\section{Background}

Afghanistan belongs to the handful non-European states that have never been colonized. ${ }^{48}$ While its exposed location between the British and Russian Empires invited external interference, and while the definite borders of the country were largely the result of the interests of these two imperial powers, it must be stressed that at no point was any meaningful external presence in the country established. The often used characterization of Afghanistan as a "buffer state" is not inaccurate in the sense that it separated the two empires, ${ }^{49}$ but the implication that the country as such is a colonial construct is a misleading one.

With the possible exception of the Pashtunistan question, ethnic diversity in Afghanistan and the existence of trans-border ethnic kinship networks cannot be seen as the result of colonial meddling - as has been the case in many African countries. At any rate the conflict must not be

46 Section V (1) of the Bonn Agreement.

47 ICG, Asia Briefing No. 35, Afghanistan: Getting Disarmament Back on Track of 23 February 2005, 2.

48 The others are Japan, Iran, Thailand, Ethiopia, Mongolia, Nepal, Bhutan and China; some include Liberia.

49 This is most clearly reflected in the unusual shape of the country, in particular the north-eastern "finger" of the Wakhan Corridor. 
seen simply as the expression of ethnic rivalry that could have been avoided if the political borders had corresponded better to ethnic realities. It is not easily conceivable how, given the extreme ethnic diversity and the widely interspersed settlement patterns, political and administrative units could be devised with ethnic representation in mind.

\section{History of the State}

Afghanistan looks back onto a very old and eventful history, having fallen at various times under Persian, Greek, Mongol, and Indian influence..$^{50}$ The political organization of the territory was very much dominated by its geographic location. ${ }^{51}$ The first Afghan state was created in 1747 when Ahmad Khan Abdali proclaimed himself king.

By 1707 there had already been a rebellion against Persian rule during which Mirwais Hotaki seized Kandahar and had himself proclaimed king by a Loya Jirga ${ }^{52}$ summoned for this occasion. ${ }^{53}$ This attempt proved, however, short-lived, and it was only the internal collapse of the Persian Empire that created the opening for the establishment of an Afghan state. Because no historical precedent for Afghan statehood existed, recourse was had in both 1707 and in 1747 to the traditional Pashtun instrument of a Loya Jirga to legitimize rule. ${ }^{54}$ This state was founded on the consent of Pashtun tribal leaders who were brought to-

50 For a short overview see G. Moltmann, "Die Verfassungsentwicklung Afghanistans von 1901 bis 1986”, Jabrbuch des Öffentlichen Rechts 35 (1986), 509 et seq. (516-519). For a more extensive treatment refer to O. Caroe, The Pathans, 1962; L. Dupree, Afghanistan, 1973; M. Klimburg, Afghanistan, 1966, Chapters I-III; K. Jäckel, “5000 Jahre Geschichte”, in: W. Kraus (ed.), Afghanistan, 1975; G. Macmunn, Afghanistan - From Darius to Amanullah, 1929.

51 Rubin, see note 24,19 , which provides a very succinct and insightful historical placement.

52 The Pashtu term Loya Jirga (grand/great assembly/council) refers to a century-old forum, in which tribal elders came together to consult and decide on conflicts, social reforms, or other important issues.

53 R. Bachardoust, Afghanistan - Droit constitutionnel, histoire, régimes politiques et relations diplomatiques depuis 1747, 2003, 18 et seq.

54 For more details see S.Q. Reshtia, "La Loya Jerga”, Central Asian Survey VII (1988), 6 et seq. 
gether in the Loya Jirga, and the very term "Afghan" remained for a long time synonymous for "Pashtun". 55

This first state was decidedly pre-modern in the sense that it was built upon the existing tribal loyalties and laws, mimicking on the "national" level the traditional power structure of personified leadership complemented by a council of elders that existed on all levels of Pashtun tribal organization. ${ }^{56}$ This foundation of the Afghan state on Pashtun tribal tradition is interesting for two reasons. First, the absence of any explicit religious reference is noteworthy: ${ }^{57}$

"En effet, aucun mollah n'y était présent en tant que tel. Aucune règle religieuse n'a été retenue pour encadrer le processus de désignation du roi. La Loya Jirga ne donna aucun titre religieux à l'heureux élu; il n'est appelé ni émir ni calife ni commandeur des croyants, mais tout simplement roi". ${ }^{58}$

Secondly, tribal tradition saw the jirga as the embodiment of the "sovereign" power of the community, being the carrier of both "legislative" 59 and adjudicating powers. The leader on each hierarchical level, the khan, was seen as the "executive power of the community subject to the will of the collectivity and the customary law of the tribe" 60 to be elected from among the dominant family. The system has not been pe-

55 “Die Paschtunen sind die eigentlichen Afghanen.” Moltmann, see note 50. Likewise, Bachardoust, see note 53, 23: "Le mot Afghan était à l'époque synonyme de Pashtoun." See also C. Schetter, "Die Territorialisierung nationaler und ethnischer Vorstellungen in Afghanistan”, Orient 44 (2003), 75 et seq.

56 Moltmann, see note $50,515$.

57 This tradition was not lost on the Taliban who not only changed the name of the country to the Islamic Emirate of Afghanistan, but also chose the title of amir al-mu'minin (Commander of the Faithful), a historic title referring to the caliph, when an assembly of 1,200 ulema met in Qandahar from 20 March to 4 April 1996 to elect Mullah Muhammad Omad as the new head of state.

58 Bachardoust, see note 53, 19.

59 The use of such quintessentially modern terms in the context of a premodern society is problematic. A society dominated by an ancient tribal customary law such as the Pashtunwali is obviously not easily inclined towards the concept of making new laws. Still the jirgas could impose new binding rules, which is the essence of the legislative power.

60 Moltmann, see note 50, 515. 
culiar to Afghanistan, and it has indeed been likened to pre-modern European political systems. ${ }^{61}$

Whether this system can be seen as proto-democratic, is problematic. It does, however, show the relatively weak claim to power exercised by the king, who from the very beginning left the tribes largely to their own devices in the regulation of their internal affairs. While it is certainly possible to see the Loya Jirga as a loose form of parliamentary representation, ${ }^{62}$ the main difference lies in the fact that the Afghan state was never able to effectively impose taxation - with or without participation - onto its subjects, remaining exceedingly weak throughout its existence. Without restating the dynastic history of the 19th century that has been covered elsewhere, ${ }^{63}$ it shall suffice to point out that the main characteristics of the Afghan state was its inability, indeed unwillingness, to impose any form of national organization or identity beyond keeping the royal family nominally in power.

The absence of a nation corresponding to the state is not peculiar to Afghanistan, but has been a dominant characteristic particularly of African post-colonial states. ${ }^{64}$ In Afghanistan, however, even the attempt to foster national unity was not undertaken as the state throughout its existence depended on received income in the form of external economic and military aid and was thus not dependent on tapping national sources of power. What Rubin says about the reign of King Abdul Rahman Khan (reigned 1881-1901) is quite symptomatic of most Afghan governments throughout its modern history:

"Abdul Rahman Khan used these coercive resources to establish the basic state structures that endured until the fall of Najibullah in 1992: a Pashtun ruler using external resources to reign over an ethnically heterogeneous society while manipulating that social segmentation to weaken society's resistance". ${ }^{65}$

61 Schwager for instance compares it to the constitution of the Germanic tribes, see J. Schwager, Entwicklung Afghanistans als Staat, 1932, 22 et seq.

62 Moltmann, see note 50, 520.

63 See the references in note 50; Rubin, see note 24,45 et seq. provides an excellent account of the process of state formation.

64 The uti possidetis decision of the Pan-African Congress of Addis-Ababa of 26 May 1963 accepted the impossibility of replacing the artificial boundaries drawn at the Berlin Conference of 1885, instead charging the African states with the task of fostering national communities beyond ethnic lines. 
Given the difficult terrain, most Afghans had traditionally led very localized lives, both physically and in terms of political loyalty. The conflict that erupted in 1978 and the mass exodus that ensued brought Afghans into contact with other Afghans from different parts of the country and ethnic background, often for the first time in living memory. Prior to 1978 loyalties and identities were mainly based on kinship ties which had only a very tenuous link to territorial units. The dual impact of the foreign invasion and the subsequent extreme political fragmentation among the mujabideen forces, which brought with it the very real threat of dismemberment of Afghanistan, changed the perception of the national territory among ordinary Afghans. ${ }^{66}$ Prior to 1978 being a citizen of the Afghan state meant little to an ethnically and geographically divided population. ${ }^{67}$ It was only through the experience of exile and resistance that the idea of the nation as a "communaute de destin" 68 gained ground. While ethnic divisions persist, most Afghans today strongly identify with the Afghan nation. Surely, in the absence of other meaningful political units, distributional struggles over power and resources continue to be expressed in ethnic terms but being part of the nation as such is no longer controversial for all ethnic groups. What successive Afghan governments failed to undertake has thus been achieved by default: the forging of a national identity, albeit at the cost of a long and painful conflict. What remains to be done, however, is the other major omission of all previous Afghan governments; the creation of an efficient state:

"The fundamental need in Afghanistan is not nation building, as is so often said. ... Afghanistan is a nation, though disputes over how to govern and share power in that nation are acute. What Afghanistan needs above all is assistance in building a state". ${ }^{69}$

In Huntington's classic institutional definition, political order is maintained through stable institutions as intermediaries that moderate the opposing political claims made by different interest groups, socialize behavior and allow for negotiated outcomes. They are characterized by their degree of stability, the importance attached to them by actors

66 Schetter, see note 16.

67 Rubin, see note 24, 22.

68 Bachardoust, see note 53, 21; see also the discussion of the Nietzschean concept of "brauchbare Vergangenheit" in the article by R. Utz, in this Volume.

69 B.R. Rubin, Statement to Implementation Group, 2002, <www.af/ resources/itsa/ig-october/B-Rubin-IGoct02.pdf>. 
and thus their ability to bring about a particular type of behavior: "Institutions are stable, valued, recurring patterns of behaviour. Organisations and procedures vary in their degree of institutionalization." 70

In Afghanistan formal institutions barely existed; for most of its history political power was based merely on unstable, frequently changing personal loyalties ${ }^{71}$ that, even with respect to the royal family, never achieved the degree of institutionalization that, according to Huntington, can produce order. In Afghanistan very few of such recurrent, stable and valued institutions existed, the most important probably being the Loya Jirga which has its origin in Pashtun tribal culture as shown above. $^{72}$

The state as such, however, always remained extremely weak and did not figure prominently in the life of ordinary Afghans whose primary loyalties belonged to smaller, non-territorial groupings such as family, clan, and tribe. The state and its territorial space carried only a very abstract, often negative connotation because it only made itself felt through the sporadic attempt to impose levies and custom duties, military and labor service. ${ }^{73}$

As mentioned earlier, the weakness of the state must not be interpreted as the absence of law as an ordering system among Afghans. The expectation of empirical validity is generally backed by the threat of sovereign sanction, but Weber conceded that the "coercive apparatus ... whose special task it is ... to apply specially provided means of coercion (legal coercion) for the purpose of norm enforcement" need not necessarily be the state, but norms can also be efficiently enforced through psychological as well as physical means of coercion, operating either directly or indirectly against the participants in the system. ${ }^{74}$ This defini-

S.P. Huntington, Political Order in Changing Societies, 1968, 12.

71 Schetter, see note 55; C. Noelle, State and Tribe in Nineteenth Century Afghanistan: The Reign of Amir Dost Muhammad Khan (1826-1863), 1997; C. Noelle, "Es ist ein weiter Weg nach Bukhara. Raum-Zeit Koordinaten in der Sichtweise afghanischer Chroniken", in: R. Haag-Higuchi/ C. Szyska (eds.), Erzäblter Raum in Literaturen der islamischen Welt, 2001, 131 et seq. (76).

72 Reshtia, see note 54 .

73 Schetter, see note $55,80$.

74 Ibid. 
tion is broader than the orthodox positivist account ${ }^{75}$ which depends solely on the threat of sovereign executive sanction to explain efficacy.

In Afghanistan most norm enforcement relied on informal mechanism not controlled by the state, such as the norms of the traditional tribal law of the Pashtuns (Pashtunwali) that were enforced though tribal councils (jirgas) at the different hierarchical levels of tribal organization. The modern state, however, that was gradually being built never achieved a particularly strong grasp over people's lives. More importantly, it's use by a very small but ideologically highly motivated group to push through radical modernization and social change quickly mobilized massive resistance. The struggle that ensued between Communist modernizers and a reluctant population quickly led to the complete demise of those state structures that had hitherto been built. Rubin sums up the history of Afghan resistance as such:

"The underlying story was about the breakdown, indeed the fragmentation, of social control and social power in Afghanistan. The painstakingly constructed state shattered when a Soviet-supported Communist elite tried to use that fragile apparatus as an instrument of massive, coercive social change". ${ }^{76}$

The particular tragedy of Afghanistan lies in the fact that in the course of the resistance not only was the state thoroughly destroyed, but also, due to the way external aid was channeled to various, mostly religiously defined groups, as well as the way the Soviet Union attempted to win the counterinsurgency war, traditional sources of social cohesion were likewise seriously affected. Towards the end of the Soviet occupation, the country was left with no legitimate government, no national leadership, a secular intelligenzia that had been very small to begin with, but had been so diminished by successive purges as to be no longer existent, multiple competing armed factions in virtually every locality of the country, and with massive population displacements.

75 In the Anglo-Saxon legal tradition this is most often identified with Austin's "command theory" which states that real law needs an enforcing sovereign, and that, therefore, international law cannot be regarded as law at all, but merely as non-binding morality, J. Austin, The Province of Jurisprudence Determined, 1832 (208). Hart in his restatement of legal positivism reaffirms essentially the same position in slightly more accommodating terms by defining a full legal system as consisting of "primary" and "secondary" rules, the latter being those that determine how the former are created, see H.L.A. Hart, The Concept of Law, 1994 [1961]. 
Thus, not only was the weak state destroyed, but also the traditional society was heavily affected.

\section{Civil Society}

As in virtually every other post-conflict scenario there has been a heavy emphasis on strengthening "civil society" in Afghanistan. ${ }^{77}$

The term defies easy classification, but there seems to be some consensus that it comprises those social relations based on the association of people independently of the state and the family, thus being composed of voluntary associations that allow "citizens to protect themselves from the state and also influence it through associative life". ${ }^{78}$ From its inception in the Scottish enlightenment to dissident movements in Central and Eastern Europe and beyond, use of the concept has always started from the assumption of a strong state against which protection and means of influence were sought. ${ }^{79}$

Civil society is thus something that is defined in opposition to the state. ${ }^{80}$ However, the problem of transition from an authoritarian police state to a liberal democratic polity ${ }^{81}$ radically differs from the creation of functioning state structures in the first place. In the latter the challenge lies in strengthening the state as such, because only the state can act as a guarantee against domestic anarchy.

77 M. Ottaway/ T. Carothers (eds), Funding Virtue: Civil Society Aid and Democracy Promotion, 2000.

78 G. Wylie, Dysfunctional Societies are not Civil Societies ... Or are They?, Conference of Civil Society, University of Belfast, 2004, 2.

79 See inter alia J. Keane, Civil Society: Old Images, New Visions, 1998; R. Hefner (ed.), Democratic Civility: The History and Cross-Cultural Possibility of a Modern Political Ideal, 1998; J. Cohen/ A. Arato, Civil Society and Political Theory, 1992; Z. Pelczynski, The State and Civil Society: Studies in Hegel's Political Philosophy, 1984.

80 A. Arato, "Civil Society versus the State", Telos 47 (1981), 23 et seq.; M. Bernhard, "Civil Society and Democratic Transition in East Central Europe”, Political Science Quarterly 108 (1993), 307 et seq.

81 M. Kaldor/ I. Vejvoda, Democratisation in Central and East European Countries, 1997; J.J. Linz/ A. Stepan, Problems of Democratic Transition and Consolidation: Southern Europe, South America, and Post-Communist Europe, 1996. 
As we have argued above, formal instruments of governance have always remained embryonic in an exceedingly weak Afghan state. But weak as it might have been, the state at the very least provided the framework in which traditional forms of societal organization could function. The ensuing conflict destroyed both the state and much of the informal arrangements that had ordered life for ordinary Afghans. The problem here is not an overly oppressive, intrusive state but its very absence.

\section{Political Society}

Inflationary use of the term "civil society" has, unfortunately, deprived it of much of its explanatory significance. In the sense conceived by Gramsci, civil society is but the complement to "political society", and it is the original creation of the latter that we are faced with in Afghanistan today, namely the creation of effective coercive instruments to empower the state to take and enforce decisions. ${ }^{82}$ The naïve insistence on giving support to "civil society" forgets that without order institutions cannot function, disregarding for the moment that in the Afghan context the very concept of liberal institutions appears problematic. This point is echoed by Goodhand:

82 A. Gramsci, Selections from the Prison Notebooks, 1971, 352. Important in this respect is his concept of cultural or intellectual begemony as a vital complement to material coercive power. Any system of power is based on the existence of coercive power. Much more effective, however, is exercising power through the consent of the ruled, which is achieved through cultural hegemony that effectively precludes the very conceptualizing of alternative power structures, thereby producing legitimacy and deference: “To the extent that this prevailing consciousness is internalised by the population it becomes part what is generally called "common sense" so that the philosophy, culture and morality of the ruling elite comes to appear as the natural order of things," B. Burke, “Antonio Gramsci and informal education", The Encyclopaedia of Informal Education, 2004, <http://www. infed.org/thinkers/et-gram.htm>. The dual dynamic of coercion and consent implicit in all power relations is reflected in Gramsci's division between political society which represents the coercive institutions such as army, police, judiciary, bureaucracy, etc. and civil society which comprises non-coercive public institutions such as churches, schools, trade unions, political parties, cultural associations, etc. In this rather subtle theory of power the task of civil society is to further the dominant normative vision that supports the status quo distribution of material power. 
"there is no getting away from the fact that state building involves the deployment of raw power and not simply the creation of liberal institutions. ... A strong state is required in order to accelerate economic development and poverty reduction, consolidate peace, reduce the scope for extreme brutality and exploitation of social relations and withstand the intrusive interest of regional powers". ${ }^{83}$

Why states fail, or more accurately in the case of Afghanistan, fail to form is a highly complex issue outside the scope of the present paper. $^{84}$ In Afghanistan we need to acknowledge the fact that the creation of state institutions did not always keep pace with the claims to sovereignty extended by the central ruler.

\section{The Path to the Bonn Agreement}

\section{Previous UN Involvement}

The UN had been active in Afghanistan even before the conflict broke out. It was engaged in normal development assistance work. In response to the Soviet intervention, the Security Council met in 1980 to consider an appropriate response but a draft resolution faltered due to the Soviet veto and the issue was referred to the General Assembly which debated it in an Emergency Special Session on Afghanistan which lasted for five days, from 10-14 January 1980, ${ }^{85}$ resulting in the first of a series of annual resolutions. ${ }^{86}$ In addition, from 1985 on the

83 Goodhand, see note 26, 168, 167.

84 For a preliminary discussion see, inter alia, R.I. Rotberg (ed.), When States Fail: Causes and Consequences, 2004; R.I. Rotberg (ed.), State Failure and State Weakness in a Time of Terror, 2003; W.I. Zartman (ed.), Collapsed States: The Disintegration and Restoration of Legitimate Authority, 1995.

85 S/RES/462 (1980) of 9 January 1980, calling on the General Assembly to examine certain questions contained in Doc. S/Agenda/2185.

86 Doc. ES-6/2 of 14 January 1980, General Assembly - Sixth Emergency Special Session "The situation in Afghanistan and its implications for international peace and security.". The following resolutions carry the same title. A complete list of the annual resolutions can be found at $<$ http://www. unama-afg.org/docs/_UN\%20Docs/_sc/resolutions.htm >. 
General Assembly began to look into the human rights situation ${ }^{87}$ resulting in a series of annual resolutions on human rights. ${ }^{88}$ Throughout the period of the conflict humanitarian assistance was being provided by the respective UN agencies, ${ }^{89}$ harmonized by the Coordinator for UN Humanitarian and Economic Assistance Programs as Operation Salam. ${ }^{90}$

The political changes initiated by Michail Gorbachev made a resolution of the conflict possible; the UN offered its good offices resulting in a series of agreements concluded between Afghanistan (i.e. the Communist Najibullah government), Pakistan, the USSR and the United States in Geneva, which provided the legal basis for the withdrawal of foreign troops. ${ }^{91}$ The Secretary-General thus established, with the authorization of the Security Council, ${ }^{92}$ the United Nations Good Offices Mission in Afghanistan and Pakistan (UNGOMAP) ${ }^{93}$ consisting of a military section under the Finnish General Rauli Helminen, ${ }^{94}$ and a po-

87 The newly appointed Special Rapporteur on Human Rights in Afghanistan delivered his first annual report in 1985. The Austrian jurist Felix Ermacora was Special Rapporteur from 1984 to 1995.

88 A/RES/40/137 of 13 December 1985 entitled "Questions of human rights and fundamental freedoms in Afghanistan”.

89 UNICEF, UNDP, UNHCR, and WFP.

90 Responsibility for the Operation passed in 1991 to Benon Sevan the Personal Representative of the Secretary-General.

91 Agreements on the Settlement of the Situation Relating to Afghanistan, concluded at Geneva on 14 April 1988 under UN auspices, commonly referred to as the "Geneva Agreements". The format that was agreed upon by the Personal Representative of the Secretary-General, Diego Córdovez with Kabul and Islamabad during talks in April and May 1985 was a series of bilateral agreements on non-interference and non-intervention, a declaration on international guarantees by the USSR and the US, a bilateral agreement on the voluntary return of refugees, an agreement between the USSR and Afghanistan on the withdrawal of troops, and an instrument that would set out the relationship between these bilateral agreements. For a contemporary discussion see R. Klass, "Afghanistan: The Accords”, Foreign Aff. 66 (1988), 25 et seq.

92 S/RES/622 (1988) of 31 October 1988.

93 The diplomatic history, the legal basis and the mandate for UNGOMAP is well presented in United Nations, Repertory of Practice of United Nations Organs, Supplement No. 7, 1989, article 98, paras 364-372.

94 Further information can be found on the website of the Finnish Defence Forces (in Finnish): <www.mil.fi/rauhanturvaaja/historia/ex_ungomap_ osgap.dsp $>$. 
litical section under Benon Sevan. The mission was mandated to oversee the withdrawal of foreign troops and authorized to receive complaints from both sides about alleged improper implementation of the Agreements.

With the lapse of UNGOMAP's mandate, one year after the Soviet withdrawal, the Office of the Secretary-General in Afghanistan and Pakistan (OSGAP) ${ }^{95}$ was established on 15 March 1990, which mirrored the dual set-up of a military and a political component. The latter was headed by Benon Sevan as the Personal Representative of the Secretary-General. OSGAP drafted a transition plan once the United States and the Soviet Union suspended military aid to their respective factions and declared their support for a UN-sponsored transfer of power to an interim government. The transition plan elaborated by Sevan, however, "broke down with the disintegration of the state that the interim government was supposed to rule." 96 As fighting intensified in 1992 the mujabideen closed in on Kabul and brought down the Najibullah government. ${ }^{97}$

The end of the Communist government also meant the end of the unifying force of a common enemy that had hitherto unified the diverse and factitious mujabideen alliance, which was unable to agree on a successor government and quickly turned against each other, heavily supported by external powers that pursued regional interests through proxies. There had been an agreement signed in Peshawar on 24 April 1992 by all mujabideen forces ${ }^{98}$ - with the notable exception of Gulbuddin Hekmatyar - to form a government under Sigbatullah Mojaddedi as head of a Transitional Council for two months that would

95 Report of the Secretary-General, The Situation in Afghanistan and its Implications for International Peace and Security, Doc. A/45/635-S/21879 of 17 October 1990, para. 21.

96 Rubin, see note 24, 269. For an overview of various prior UN initiatives see M.K. Ma'aroof, United Nations and Afghanistan Crisis, 1990.

97 Najibullah sought refuge in the UN compound where he remained until 1996. Despite repeated pleas by the Secretary-General he was not assured safe passage. After the Taliban took control of Kabul, they abducted Najibullah and his brother on 26 September 1996 and subsequently executed them. The action was strongly condemned by the General-Assembly in Resolution 51/108, para. 10 of 12 December 1996, and the Security Council Statement Doc. S/PRST/1996/40.

98 For a discussion of the legal and constitutional implications of the Peshawar Accord see Bachardoust, see note 53, 235 et seq. 
then be replaced by a Leadership Council under Burhannudin Rabbani for four months.

In July 1992 the Islamic State of Afghanistan was proclaimed as the successor to the Democratic Republic of Afghanistan, with Rabbani as its president. The General Assembly welcomed the establishment of the state, seeing it as "provid[ing] a new opportunity for the reconstruction of the country," 99 underlined "the importance of the rehabilitation and reconstruction of Afghanistan", 100 whose development had suffered during the previous fourteen years of war, and "affirmed the urgent need to initiate international action to assist Afghanistan in restoring basic services and in rebuilding the country". ${ }^{101}$

According to the Peshawar Accord Rabbani was supposed to relinquish power in October, but he refused to do so. Hekmatyar who had stayed outside the Accord had never accepted the legitimacy of the new government, and by that time heavy fighting had erupted between his forces and those loyal to the government, commanded by Ahmad Shah Massoud, the minister of defense of the Islamic State. Throughout the Soviet occupation the larger cities, and especially Kabul, had remained under firm control of the government and had thus been spared from destruction. The fighting that broke out between the various mujabideen factions, on the contrary, centered on the control over the cities, resulting in heavy damage, especially in Kabul.

In the subsequent fighting the Peshawar Accord unraveled, and the mujabideen factions turned against each other in a bewildering succession of alliances, counter-alliances, betrayals, and severe atrocities committed by all against all. There were two peace accords ${ }^{102}$ signed in 1993, on 7 March in Islamabad and on 18 May in Jalalabad, between Rabbani and eight other faction leaders (though, again, not with Hekmatyar) which established an interim government for eighteen months, in which period the drafting of a new constitution through a constituent assembly and the preparation of an electoral process was to take place. Unfortunately these attempts were not successful.

$99 \mathrm{~A} / \mathrm{RES} / 47 / 119$ of 18 December 1992, preambular para. 1.

100 Ibid., preambular para. 5 .

101 Ibid., preambular para. 7.

102 The so called Islamabad Accords were signed with the support of Pakistan, Saudi Arabia and Iran. The UN was not involved in the process. For details, see Rubin, note 24, 271-274. 
Under the influence of the continued heavy fighting the General Assembly requested the Secretary-General in December 1993 to establish the United Nations Special Mission in Afghanistan (UNSMA) ${ }^{103}$ with a more active mandate of "facilitating national rapprochement and reconstruction," beyond merely monitoring events and reporting them. ${ }^{104}$ The former minister of foreign affairs of Tunisia, Mahmoud Mestiri, was thus appointed on 12 February 1994 as Special Envoy of the Secretary-General and headed UNSMA. He was succeeded in May 1996 by Dr. Norbert Holl, who resigned effectively on 29 December 1997. His deputy James Ngobi took over as acting head until the appointment of Lakhdar Brahimi in July 1998.

Given the unwillingness of the local factions to come to an agreement, and given further the proxy nature of much of the fighting with regional powers each pursuing their own political and ideological ends through their economic and military support of competing mujabideen groups, it should come as no surprise that UNSMA remained largely ineffective. From its inception in 1994 until the appointment of Brahimi "UNSMA is widely regarded as making little headway, a situation that was not helped by ineffectual earlier SRSG [Special Representative of the Secretary-General] appointments". ${ }^{105}$ One of the key changes instigated by Brahimi was to recognize formally that the Afghan conflict was aggravated due to foreign interference, ${ }^{106}$ leading to the creation of the so-called Six-plus-Two Group ${ }^{107}$ comprised of the neighboring

103 A/RES/48/208 of 21 December 1993, para. 4.

104 "Invited the Secretary-General to continue to monitor the overall situation in Afghanistan and make available his good offices as required, and to report to the General Assembly”, para. 5, emphasis added.

105 M. Duffield, et al., Review of the Strategic Framework, AREU, 2001, 31; likewise: B.R. Rubin, et al., Afghanistan: Reconstruction and Peacebuilding in a Regional Framework, Centre for Peacebuilding, Swiss Peace Foundation, 2001; M. Fielden/ J. Goodhand, Peace-Making in the New World Disorder: A Study of the Afghan Conflict and Attempts to Resolve it, IDPM Manchester/INTRAC Oxford, 2001,

106 "Deploring the fact that despite repeated pleas by the Security Council, the General Assembly and the Secretary-General to halt foreign interference in Afghanistan, including the involvement of foreign military personnel and the supply of arms and ammunition to all parties in the conflict, such interference continues unabated", S/RES/1193 (1998) of 28 August 1998, preambular para. 7.

107 "Calls upon all States neighbouring Afghanistan and other States with influence in the country to intensify their efforts under the aegis of the 
countries (Pakistan, Iran, Uzbekistan, Tajikistan, Turkmenistan and China) plus Russia and the United States.

The explicit mandate of UNSMA and of the SRSG has been throughout to bring all Afghan factions together to negotiate a settlement. However, as the language of the respective Security Council resolutions indicates, it became increasingly clear that the Taliban were not willing to negotiate in good faith, ${ }^{108}$ and that active military support by regional powers, especially Pakistan, continued unabated, despite repeated Security Council resolutions to the contrary. ${ }^{109}$

Furthermore, at least after the bombings of the US embassies in Nairobi and Dar-es-Salaam in 1998, the possible involvement of al Qaeda became more apparent. ${ }^{110}$ The Security Council condemned the

United Nations to bring the parties to a negotiated settlement;” ibid., para. 4.

108 "Deploring the fact that despite the readiness of the United Front of Afghanistan [the Northern Alliance] to conclude a durable ceasefire and to enter into a political dialogue with the Taliban, fighting continues on both sides, [...]", S/RES/1214 (1998) of 8 December 1998 preambular para. 3; "Reiterates its very strong support and appreciation for the continuing efforts of the Special Envoy of the Secretary-General to secure the full implementation of its resolutions and demands that all parties, in particular the Taliban, cooperate in good faith with these efforts;" ibid., The Taliban failed to respond either to the requests to take actions against preparatory activities by terrorists (S/RES/1214 (1998) of 8 December 1998; S/RES/1267 (1999) of 15 October 1999; S/RES/1333 (2000) of 19 December 2000; S/RES/1378 (2001) of 14 November 2001), or to the requests to turn over Osama bin Laden (S/RES/1267 (1999) of 15 October 1999; S/RES/1333 (2000) of 19 December 2000).

109 S/RES/1214 (1998) of 8 December 1998, para. 10; S/RES/1193 (1998) of 28 August 1998, preambular para. 7, para. 3; S/RES/1076 of 22 October 1996, paras. 3,4 .

110 It is interesting to note that on 20 August 1998 US President Bill Clinton ordered "Operation Infinite Reach", i.e. retaliatory cruise missile strikes against alleged terrorist bases in Afghanistan, as well as a pharmaceutical plant in Sudan alleged to have been involved in the manufacture of chemical weapons. The latter allegations could not be substantiated by later onsite investigations. Usama bin Laden and Muhammad Atef were indicted for their involvement in the embassy bombings on 4 November 1998 in Manhattan Federal Court. The indictment included the alleged claim that there had been cooperation between al-Qaeda and the government of Iraq. See <http://usinfo.state.gov/is/Archive_Index/Bin_Laden_Atef_Indicted_ in_U.S._Federal_Court_for_African_Bombings.html>. 
attacks and called upon Member States to fully cooperate with Kenyan, Tanzanian and US authorities to bring the perpetrators to justice without, however, explicitly mentioning Afghanistan or the Taliban. ${ }^{111}$ With mounting evidence of al Qaeda involvement, the Security Council adopted a tougher stance and imposed sanctions on the Taliban government for "continu[ing] to provide safe haven to Usama bin Laden and to allow him and others associated with him to operate a network of terrorist training camps from Taliban-controlled territory and to use Afghanistan as a base from which to sponsor international terrorist operation". ${ }^{112}$

In many respects this constituted the crossing of the Rubicon for the efforts of the UN in Afghanistan, because it had become apparent now that the efforts of coming to a negotiated settlement with the Taliban had not only remained ineffective, as already indicated in Resolution 1214 (1998), but that furthermore the international community had finally identified the Taliban as part of the problem, and no longer a possible component of the solution.

Coinciding with this tougher line taken by the Security Council, ${ }^{113}$ the Secretary-General and his Special Representative agreed that under the given circumstances and given the lack of progress towards a negotiated settlement his further involvement would serve little purpose. ${ }^{114}$ Although not stated explicitly, this decision was partly motivated by the continued strong military interference of the neighboring countries, especially Pakistan's supply of military advisors, arms, and manpower to the Taliban which made them more intransigent than ever. ${ }^{115}$ Despite

111 S/RES/1189 (1998) of 13 August 1998, para. 3.

112 S/RES/1267 (1999) of 15 October 1999.

113 S/RES/1333 (2000) of 19 December 2000 which reiterated the demand to cooperate with the political process led by the SRSG, to hand over bin Laden, and in a thinly veiled reference to Pakistan and Saudi Arabia, to withhold military support and to scale back diplomatic contacts. The tone was further sharpened through S/RES/1363 (2001) of 30 July 2001 which established the so-called Monitoring Group and the Sanctions Enforcement Support Team to implement the sanctions imposed through S/RES/1267 (1999) of 15 October 1999 and S/RES/1333 (2000) of 19 December 2000.

114 " $[\mathrm{M}] \mathrm{y}$ Special Envoy and I have reached the conclusion that given the lack of progress achieved so far, his activities should be "frozen" until such time as circumstances change to justify his renewed intervention.” Annual Report of the Secretary-General on Afghanistan, Doc. A/54/536-S/1999/1145, Sec. VIII of 16 November 1999.

115 Duffield, et al., see note $105,31$. 
Brahimi's resignation, the mandate of UNSMA was upgraded. While it had, since its inception, been formulated in the following relatively general terms, namely "to mediate an end to the conflict and to facilitate the implementation of a comprehensive peaceful settlement" ${ }^{\text {"16 }}$, the Secretary-General now stated that it was to "assume the primary role in conducting United Nations peacemaking activities in Afghanistan. It is my intention to appoint a substantive Head of the Mission at the Assistant Secretary-General level". ${ }^{117}$

The General Assembly endorsed these recommendations of upgrading UNSMA and to progressively move the mission from Islamabad to Kabul and to increase its presence in the neighboring countries. ${ }^{118}$ Francesc Vendrell was appointed on 12 January 2000 as the new Personal Representative and Head of UNSMA, ${ }^{119}$ while Brahimi served as Under-Secretary for Special Assignments, chairing the independent panel convened by Secretary-General Annan on 7 March 2000 to review the UN preventive and peacemaking efforts. This panel delivered its report on 17 August 2000, 120 and much of the approach taken by UNAMA later on draws on the lessons suggested in this report, in particular the attempt to coordinate all UN efforts, i.e. both military peacekeeping, civilian police aspects, political affairs, humanitarian assistance, as well as physical and institutional reconstruction provided by many different UN agencies and organs into a coherent and integrated structure.

\section{Consequences of the "Brahimi Report"}

One of the findings of the Brahimi report that was subsequently implemented in the approach taken by the UN with regard to Afghanistan after September 11, was the special emphasis on a robust peace-keeping force able to defend itself and its mandate. Previously the UN had often sent blue helmets into situations where "the parties to the conflict were not seriously committed to ending the confrontation. United Nations

$116 \mathrm{~A} / \mathrm{RES} / 51 / 195$ of 17 December 1996.

117 Doc. A/54/536-S/1999/1145, Sec. VIII, emphasis added.

118 A/RES/54/189 A of 17 December 1999.

119 Doc. A/54/706-S/2000/20 of 14 January 2000.

120 Report of the Panel on United Nations Peace Operations, Doc. A/55/305$\mathrm{S} / 2000 / 809$, commonly referred to as "Brahimi Report", <www.un.org/ peace/reports/peace_operations/>. 
operations thus did not deploy into post-conflict situations but tried to create them." 121 The conceptual distinction thus had to be made between peace-keepers and peace builders; where there was no peace to be kept, a robust force with a strong mandate was required to enforce it.

The report furthermore accepted that it was unlikely that such troops would be forthcoming under UN auspices. The politicized nature of UN troop deployment made even minor tactical decisions unacceptably slow. Classical UN peace-keeping so far had relied on the troop contributions of a relatively small number of countries. Peaceenforcement, however, required larger military capabilities that these nations were not able to muster. The report advocated the concept of "subcontracting" peace-enforcement to interested national or regional contingents, which would remain under national command without being subordinate to a Commander-in-Chief appointed by the SecretaryGeneral. In his report to the Security Council on 13 November 2001 Brahimi laid out his strategic vision for the UN's role in Afghanistan and remarked on the issue of security provision:

"An armed UN peacekeeping force is not recommended. The Secretary-General would require several months to obtain from Member States sufficient numbers of troops to pose a credible military deterrent, and to subsequently deploy them. Furthermore, UN peacekeepers have proven successful when deployed to implement an existing political settlement among willing parties - not to serve as a substitute for one". 122

The other noteworthy aspect that found its way from the report into implementation in Afghanistan was the close operational and strategic coordination through an Integrated Mission Task Force (IMTF) at headquarters and through pooling available funds and various donor activities on the ground through one channel (trust funds and UNAMA) that could provide the necessary strategic vision and coordination.

121 Ibid., Executive Summary.

122 Brahimi, see note 41. 


\section{Present UN involvement and the Bonn Agreement}

\section{a. Events Leading to Bonn}

The terrorist attacks of September 11 had changed the situation on the ground dramatically. The attacks were condemned by both the General Assembly ${ }^{123}$ and the Security Council, ${ }^{124}$ and the involvement of al Qaeda quickly became apparent. ${ }^{125}$ US President Bush thus delivered on 20 September 2001 an ultimatum to the Taliban regime to hand over the al Qaeda leaders, and verifiably close down the alleged terrorist camps. ${ }^{126} \mathrm{Few}$ believed that, given their ideological stance as well as their dependency on al Qaeda for financial, logistic, and military support, the Taliban were in a position to accept the terms offered.

On 6 October 2001 President Bush informed Congress that the demands had not been met and that military action would commence the next day. The military campaign was supported by a number of countries and essentially used the Northern Alliance as the ground forces of the Coalition. ${ }^{127}$ It was apparent that once the military campaign had

$123 \mathrm{~A} / \mathrm{RES} / 56 / 1$ of 12 September 2001.

124 S/RES/1368 (2001) of 12 September 2001.

125 The short and curt statement made on 19 September 2001 by the President of the Security Council, Jean-David Levitte (France) is highly indicative in this regard: "Today there is one, and only one, message the Security Council has for the Taliban: implement United Nations Security Council resolutions, in particular resolution 1333, immediately and unconditionally." <http://www.un.org.pk/latest-dev/hq-pre-010918.htm>.

126 Address to a joint session of Congress on 20 September 2001, <http://www.whitehouse.gov/news/releases/2001/09/20010920-8.html>.

127 On the question of its legality only exemplary: R. Wolfrum, “The Attack of September 11, 2001, the Wars Against the Taliban and Iraq: Is There a Need to Reconsider International Law on the Recourse to Force and the Rules in Armed Conflict?" Max Planck UNYB 7 (2003), 1 et seq.; M. Reisman, "In Defense of World Public Order”, AJIL 95 (2001), 833 et seq.; T. Franck, "Terrorism and the Right to Self Defense", AJIL 95 (2001), 840 et seq.; C. Tomuschat, "Der 11. September 2001 und seine rechtlichen Folgen”, EuGRZ 28 (2001), 535 et seq.; E.P.J. Myjer / N.D. White, “The Twin Towers Attack: An Unlimited Right to Self-Defence?”, Journal of Conflict and Security Law 7 (2002), 5 et seq.; T. Bruha, "Gewaltverbot und humanitäres Völkerrecht nach dem 11. September 2001”, Archiv des Völkerrechts 40 (2002), 383 et seq.; S.D. Murphy, "Terrorism and the Concept of "Armed Attack" in Article 51 of the U.N. Charter", Harv. Int'l L. J. 43 (2002), 41 et seq.; D. Abramowitz, "The President, the Congress, and the 
succeeded, a political solution had to be found whose legitimacy went beyond what the United States could muster on its own. In anticipation of the military campaign, whose success was never seriously questioned, the Secretary-General re-appointed Brahimi as his Special Representative on 3 October 2001 and entrusted him with the overall responsibility for the humanitarian, human rights, and political endeavors of the UN in Afghanistan; the former head of UNSMA, Francesc Vendrell became his deputy.

On his appointment Brahimi immediately contacted the members of the Six-plus-Two Group, especially Iran and Pakistan, and canvassed their support for the settlement process towards the creation of a broad-based, multi-ethnic Afghan government, and the central role of the UN in this process. ${ }^{128}$ In his presentation of this approach to the Security Council the following day, he built upon his consultations with the Six-plus-Two and outlined in essence the roadmap followed in Bonn. ${ }^{129}$ One thing that became apparent during these consultations as well as during his presentation to the Security Council was the urgent need for speed in order to remain on top of the rapidly changing military situation. As the Northern Alliance rapidly expanded its control and entered Kabul on the very day of his presentation, it became urgent to avoid a fait accompli on the ground and to use the unprecedented window of opportunity offered by the consensus between all major backers of the four main Afghan groups. The key points outlined by Brahimi that were to guide the negotiations in Bonn were:

- only a legitimate Afghan government representing all the people could gather sufficient resolve and legitimacy to confront the hold international terrorist groups had over the country;

- the recognition of the special role, and the legitimate interests of Iran and Pakistan, as well as the ties that exist between them and certain Afghan groups;

Use of Force: Legal and Political Considerations in Authorizing Use of Force Against Terrorism”, Harv. Int'l L. J. 43 (2002), 71 et seq.; M. Krajewski, "Selbstverteidigung gegen bewaffnete Angriffe nicht-staatlicher Organisationen - Der 11. September 2001 und seine Folgen”, AVR 40 (2002), 183 et seq.

128 Declaration on the Situation in Afghanistan by the Foreign Ministers and other senior representatives of the "Six plus Two" on 12 November 2001, <www.un.org.pk/latest-dev/hq-press-011112.htm>. 
- the commitment by all parties involved, especially these two countries, towards a political solution that would preserve the unity and territorial integrity of Afghanistan;

- consensus between the neighbors, only without undue interference would the Afghans be able to arrive at a durable solution;

- the recognition that a stable Afghanistan is in the regional interest, in particular in the national interest of Iran and Pakistan, especially concerning drug production;

- the need for a broad-based, multi-ethnic, politically balanced, freely chosen government enjoying both domestic and international legitimacy;

- pivotal role of the UN in convening the negotiations and mediating between the parties, as well as in the implementation;

- undesirability to impose an external solution on the Afghans;

- need for the sustained long-term engagement of the international community in providing the necessary resources, politically and financially;

- given the rapidly changing military realities, a continuation of the shuttle diplomacy was unfeasible, and the four main groups (Northern Alliance, Rome Group (around the former King), Cyprus Group (Iranian diaspora), and Peshawar Group (Pakistani diaspora) should convene as soon as humanly possible at a convenient venue;

- these existing groups and processes would commence the negotiations, and would later be supplemented by additional representatives to ensure broad participation, but the initial lack of representativeness should not detract from the ability to agree on a framework; - to create the institutions of good governance, the aim was to formulate clear and fair rules of the game and adherence to those rules, to be sustainable, Afghans themselves needed to be engaged in their creation, with particular recourse to be had to returning diaspora Afghans; this being preferable and more legitimate than a transitional administration run by the $\mathrm{UN}^{130}$ or another constellation of foreigners;

130 For an insightful, succinct, and sympathetic account of UN administrations in East Timor, post-Dayton Bosnia-Herzegovina, Eastern Slavonia, and Kosovo, see R. Caplan, A New Trusteeship? The International Administration of War-torn Territories, 2002. 
- the deployment of a robust security force, in particular for Kabul, with preference to a multinational, non-UN force;

- Kabul was to be demilitarized and should not be controlled by any one faction;

- closely integrated UN mission implementation, with clear lines of authority and responsibility among the donors and within the UN system;

- all actors were to accept the principle that Afghans are in charge and must have ownership of the process;

- the institutions to be agreed upon were to be provisional and would, of necessity, not include every one who should have been considered, as well as including some whose credentials were questionable; in the interest of peace and considering that this was but the beginning of a process not the end point of a settlement, these shortcomings were to be accepted. ${ }^{131}$

The Taliban withdrew from Kabul on the day Brahimi presented his approach to the Security Council. Thus, Deputy SRSG Vendrell was dispatched immediately to Kabul, and the next day, on 14 November 2001, the Security Council endorsed the approach suggested by Brahimi in resolution $1378,{ }^{132}$ expressing their "strong support for the efforts of the Afghan people to establish a new and transitional administration leading to the formation of a government, both of which:

- should be broad based, multi-ethnic and fully representative of all the Afghan people and committed to peace with Afghanistan's neighbors,

- should respect the human rights of all Afghan people, regardless of gender, ethnicity or religion,

- should respect Afghanistan's international obligations, including by cooperating fully in international efforts to combat terrorism and illicit drug trafficking within and from Afghanistan, and

- should facilitate the urgent delivery of humanitarian assistance and the orderly return of refugees and internally displaced persons, when the situation permits"; 133

Furthermore, the Member States were called upon to support such a new government and administration, to provide the necessary emer-

131 Brahimi, see note 41.

132 S/RES/1378 (2001) of 14 November 2001.

133 Ibid., para. 1. 
gency relief and long-term assistance for the reconstruction process, and to support efforts to ensure the safety and security of areas of Afghanistan no longer under Taliban control. ${ }^{134}$

\section{b. The Negotiations in Bonn}

What is remarkable, particularly in light of the decades of failed attempts at international mediation, is the extremely fast pace at which the above outline was put into action. Germany offered to host the talks, which were convened less than two weeks later, on 27 November in a hotel close to Bonn. The talks were conducted under extreme time pressure, partly in order to keep pace with the fact-changing situation on the ground, and partly for quite mundane logistical reasons. ${ }^{135}$ The delegates represented the following main groups: ${ }^{136}$ the United Front for the Salvation of Afghanistan, better known as the Northern Alliance, ${ }^{137}$ a Tajik-dominated military alliance of most of the remaining non-Taliban armed formations whose main geographic stronghold had been the Panshir valley and whose troops had already occupied Kabul (and the major ministries) by the time the negotiations began in Bonn. The other groups were the so-called Cyprus group as a representation of the Dari-speaking diaspora including representatives of the Shia Hazara minority, ${ }^{138}$ residing mainly in Iran; the Peshawar group representing the Pashtu-speaking diaspora, residing mainly in Pakistan; and the Rome group around the former king, thus representing moderate, mostly Pashtun Afghans throughout the Western diaspora. ${ }^{139}$

The groups assembled in Bonn were united by little more than their opposition to the Taliban, who were themselves conspicuous by their

134 Ibid., paras 4 and 5.

135 The hotel was booked for a dentist convention after 5 December, leading to many of the key decisions, such as the selection of the ministers of the interim administration, being negotiated in the final night. See Rubin, see note 36,570 .

136 For a succinct description of the different groups see Rubin, see note 34.

137 The Northern Alliance was led in Bonn by Yunus Qanooni, and reported to Burhanuddin Rabbani, who was formally still the president of the Islamic State of Afghanistan.

138 The Cyprus group was led by Homayun Jareer, the son-in-law of Gulbuddin Hekmatyar, whose opposition had brought the first post-Communist government to fall.

139 A provisional list can be found at <www.un.org.pk/latest-dev/hq-presslist-cont-afg-provlist.htm>. 
absence. The fact that the latter were not present, and that there was only one other group with a military presence on the ground, probably made an agreement possible in the first place. Nevertheless, as has already been mentioned, this constellation perhaps also explains why the agreement did not mention any procedure to account for past atrocities. Transitional justice relies on the common acceptance by all sides to a domestic conflict that there is some legitimacy to all claims, albeit pursued through questionable means. Given the political and military realities leading up to the Bonn process, it should come as no surprise that this necessary dynamic was missing at this junction in Afghanistan. ${ }^{140}$

Apart from the issue of accountability for the past, several other issues were highly contentious during the negotiations, inter alia the question of the demobilization of the mujabideen forces, the establishment of an international security assistance force for Kabul, the role of the former king, as well as the lack of any perceived role for the nominal president Rabbani. ${ }^{141}$ There were strong divisions between Rabbani and the three moderate Tajik leaders within the Northern Alliance: the designated interior minister Yunus Qanooni, ${ }^{142}$ minister of defense General Mohammad Fahim, and minister of foreign affairs Abdullah Abdullah. Only concerted interventions by the major Northern Alliance commanders on the ground, Ismail Khan, Abdul Rashid Dustum and the Shiite Hazara leader Karim Khalili, the threat by Qanooni to openly defy him, as well as the personal intervention of the German minister of foreign affairs Fischer and SRSG Brahimi, convinced him to acquiesce.

The explicit message conveyed to him by the US special envoy and later US ambassador Zalmay Khalilzad that the US would hold ac-

140 President Karzai went on record to say that peace is a necessity and justice a luxury that Afghanistan cannot afford right now. See interview of 10 May 2002 with Lyse Doucet at <http://news.bbc.co.uk/1/hi/talking point/1940038.stm>.

141 See Rubin, see note 36, 572; for a good contemporary overview of the relevant actors and their motivations see also P. Bora, "Interim Afghan Government: First Step to Stability”, <www.subcontinent.com/sapra/regional/ regional20011206a.html>.

142 Due to a miscalculation of his, Qanooni later refused the post of interior minister planning to become prime minister under a system similar to the French presidential system. Once it became apparent that the presidential system adopted would resemble the American one without the post of a prime minister, Qanooni had to backtrack and settle for the relatively unimportant post of minister of education. 
countable anyone who opposed the peace process, might very well have proved decisive in this respect. The opposition expressed by Gulbuddin Hekmatyar (a Pashtun) who had been sidelined during the negotiations and who had denounced its conclusions as American-imposed and thus illegitimate remained largely ineffective, not least due to the same threat of decisive US action likely to be taken against him. Reflecting the situation on the ground, ethnic Tajiks were strongly represented during the negotiations, and in the interim administration that it previewed. The Pashtun majority was represented by the moderate exiles in the Rome group, as well as through the Peshawar group. The choice of the Kandahari Pashtun tribal leader Hamid Karzai as the head of the interim administration was intended to counter-balance the dominance of the Tajiks. Karzai had been deputy minister of foreign affairs in the first mujabideen government of 1992 under Rabbani, later becoming minister of foreign affairs. His family had had strong links to both Pakistan and the US, and being fluent in English as well as Urdu, yet from an old aristocratic family with close links to the king, he was seen as an ideal man able to appeal to very divergent constituencies, both domestic and international. ${ }^{143}$ The assumption that an ethnic Pashtun head of the interim administration was required to integrate the Pashtun majority into the peace process and wean them away from their allegiance to the Taliban has proved correct. Despite the initial loud denouncement of his choice by radical Pashtun leaders such as Hekmatyar, Haji Abdul Qadeer, ${ }^{144}$ Mehmood Khan Achakzai, ${ }^{145}$ or Gul Agha Sherzai, ${ }^{146}$ Karzai has subsequently proved able to integrate the Pashtun constituency through his personality, family ties, and skilled political maneuvering.

143 It is interesting to note in this respect that the former king Zaher Shah initially opposed Karzai's nomination, favoring instead the ethnic Uzbek Abdul Sattar Seerat, a former minister of justice under the king.

144 Governor of the eastern Pashtun province of Nangahar, who walked out of the Bonn negotiations on 1 December complaining about the alleged lack of representation of the Pashtun community.

145 Head of the Pakistan-based Pashunkhwa Milli Awami Party (PMAP), the Pashtun nationalist party.

146 Former governor of Kandahar, whose troops were besieging the Taliban forces in the city at the time of the Bonn negotiations. While he initially objected to the insufficient representation of the Pashtuns he later collaborated with the Karzai government and received the post of governor. $\mathrm{He}$ was dismissed and assumed a post in Kabul in August 2003. 
The negotiations in Bonn resulted in the signing of the Bonn Agreement ${ }^{147}$ on 5 December 2001. This Agreement previewed the official transfer of power to an Interim Authority on the 22 December of that year ${ }^{148}$ and laid down a very ambitious time frame for the further establishment of state institutions. The participants in Bonn were reasonably representative of the ethnic and political diversity of the country, but while certainly acceptable as a provisional measure, it was clear that it could not confer lasting democratic legitimacy. Therefore, it was agreed that an Interim Authority ${ }^{149}$ would be nominated in Bonn with a mandate for six months, ${ }^{150}$ during which time an Emergency Loya Jirga would be convened whose broader representation would allow a more legitimate basis for the Transitional Government that it would name. ${ }^{151}$ The latter would have a mandate for two years ${ }^{152}$ during which it would re-establish government structures, name a Constitutional Commission to prepare a draft constitution and organize the elections for a Constitutional Loya Jirga to be convened no later than 18 months after the establishment of the Transitional Authority in order to adopt the new constitution. ${ }^{153}$ Furthermore, the legal framework to be applicable until the adoption of a new constitution was agreed upon. ${ }^{154}$

147 “Agreement on Provisional Arrangements in Afghanistan Pending the Reestablishment of Permanent Government Institutions", see note 30.

148 Section I (1) Bonn Agreement.

149 Consisting of an Interim Administration (i.e. Cabinet) presided over by a Chairman (Karzai), a Special Independent Commission for the Convention of the Emergency Loya Jirga, and a Supreme Court as well as lower courts. Section I (2) Bonn Agreement.

150 "Noting that these interim arrangements are intended as a first step toward the establishment of a broad-based, gender-sensitive, multi-ethnic and fully representative government, and are not intended to remain in place beyond the specific period of time," preambular para. 7 Bonn Agreement; Section I (4) Bonn Agreement.

151 Section I (4), (5) Bonn Agreement.

152 Section I (4) Bonn Agreement.

153 Section I (6) Bonn Agreement.

154 Section II (1) Bonn Agreement: “i) The Constitution of 1964, a/ to the extent that its provisions are not inconsistent with those contained in this agreement, and b/ with the exception of those provisions relating to the monarchy and to the executive and legislative bodies provided in the Constitution; and ii) existing laws and regulations, to the extent that they are not inconsistent with this agreement or with international legal obligations to which Afghanistan is a party, or with those applicable provisions con- 
In view of the fact that the security situation in Afghanistan was dismal after the fall of the Taliban, and security can still not be guaranteed ${ }^{155}$ by the Afghans themselves as there are not sufficient military and police forces loyal to the central authorities, the Bonn Agreement included the request for the deployment of a UN mandated force. In the spirit of the Bonn Agreement, the request for assistance in the maintenance of security for Kabul and its surrounding areas goes hand in hand with the recognition that "the responsibility for providing security and law and order throughout the country resides with the Afghans themselves." ${ }^{156}$ Pursuant to this request, the Security Council authorized the establishment of an International Security Assistance Force (ISAF) to assist the Afghan Interim Authority to maintain security in Kabul and the surrounding areas for a period of six months. ${ }^{157}$ This period has been extended a number of times and after NATO ${ }^{158}$ took over command of ISAF, ${ }^{159}$ the international security assistance has been extended beyond Kabul. 160 The UN involvement in Afghanistan thus consists of a civil mandate combined with a multi-national military force that is not under UN command.

tained in the Constitution of 1964, provided that the Interim Authority shall have the power to repeal or amend those laws and regulations."

155 Only exemplary: "Die Armut bleibt, der Terror schwillt an" Frankfurter Rundschau of 2 June 2005; HRW, Afghanistan: Violence Surges of 23 May 2005, <http://www.alertnet.org/thenews/newsdesk/HRW/7c0146cf8972 bdfa0855036f1313505b.htm>.

156 Annex I (1) Bonn Agreement.

157 See S/RES/1386 (2001) of 20 December 2001. For the mandate see S/RES/1386 (2001) of 20 December 2001, S/RES/1413 (2002) of 23 May 2002, S/RES/1444 (2002) of 27 November 2002, S/RES/1510 (2003) of 13 October 2003, S/RES/1563 (2004) of 17 September 2004, for twelve months.

158 Report of the Secretary-General, The situation in Afghanistan and its implications for international peace and security, Doc. A/57/850-S/2003/754 of 23 July 2003 , para. 37.

159 The nations leading ISAF before NATO took over the command were: United Kingdom, Turkey, Germany and the Netherlands. See Reports of the Secretary-General, The situation in Afghanistan and its implications for international peace and security, Doc. A/56/875-S/2002/278 of 18 March 2002, para. 55; Doc. A/56/1000-S/2002/737 of 11 July 2002, para. 26; Doc. A/57/762-S/2003/333 of 18 March 2003, para. 36.

160 Report of the Secretary-General, The situation in Afghanistan and its implications for international peace and security, Doc. A/59/581-S/2004/925 of 26 November 2004, para. 37. See also note 2. 
The Bonn Agreement establishes the character of the UN involvement in Afghanistan as merely supportive, with control lying in the hands of the Afghan authorities from the very beginning of the reconstruction and peace-building process. The Preamble reaffirms "the independence, national sovereignty and territorial integrity of Afghanistan" while " $[\mathrm{a}] \mathrm{cknowledging}$ the right of the people of Afghanistan to freely determine their own political future in accordance with the principles of Islam, democracy, pluralism and social justice", and finally determines that the UN, "as the internationally recognized impartial institution, has a particularly important role to play, ..., in the period prior to the establishment of permanent institutions in Afghanistan", thereby already placing limits on the UN involvement.

It establishes that power shall be transferred to the Interim Authority only weeks after the talks in Bonn, ${ }^{161}$ confirming that "the Interim Authority shall be the repository of Afghan sovereignty, with immediate effect." 162 As stated in the preamble of the Bonn Agreement, power was thus transferred directly from the Council of Ministers headed by Rabbani ${ }^{163}$ to the Interim Authority. Legally, genuine authority continuously rested with the Afghan authorities, instead of resting with the Secretary-General of the UN and being exercised through his Special Representative. ${ }^{164}$ In accordance with the merely supportive and consultative role of the UN, the Bonn Agreement does not contain any reserved powers, even in the event of the Interim Authority not being able to decide on matters relating to the convening of the Emergency Loya Jirga, which was essential for transferring power to a body of authority legitimized by a more democratic process than the talks in Bonn. Had there been problems, the Special Representative of the Secretary-General was merely to "use his/her good offices with a view to facilitating a resolution to the impasse or a decision." 165 In relation to human rights, apart from developing and implementing a program of human rights education, the $\mathrm{UN}$ only has "the right to investigate human rights violations and, where necessary, recommend corrective ac-

161 Sovereignty was transferred to the Afghan Interim Authority on 22 December 2003.

162 Section I (3) Bonn Agreement.

163 See note 6.

164 Two examples where the UN exercised authority are the reconstruction processes of Kosovo and East Timor, which are both described in this Volume by J. Friedrich and M. Benzing.

165 See Annex II (5) Bonn Agreement. 
tion." 166 In view of this limited role accorded to the United Nations in the Bonn Agreement and in view of the fact that Afghanistan has remained a state with undisputed sovereignty throughout the long years of war, the UN has thus adopted a "light footprint" approach, focusing on building Afghan capacities and ensuring that UNAMA's tasks are carried out in close coordination and consultation with Afghan authorities. ${ }^{167}$

\section{c. UNAMA's Mandate}

The "light footprint" approach mentioned above was decisive in determining the character of UNAMA, whose definition as an "assistance" mission already reinforces the intention of the UN to follow a nonintrusive approach in Afghanistan. To deal with issues beyond ensuring security, the Security Council had endorsed the report by the SecretaryGeneral ${ }^{168}$ that called for the establishment of an UN Assistance Mission in Afghanistan (UNAMA) that was to help implement the Bonn Agreement ${ }^{169}$ and to assist in the relief, recovery and reconstruction of the country as foreseen in resolution $1401 .{ }^{170}$ The Report of the Secretary-General of 18 March $2002^{171}$ provides the mandate and structure of the mission. ${ }^{172}$ The core of the mission's mandate is defined as follows: ${ }^{173}$

“(a) Fulfilling the tasks and responsibilities, including those related to human rights, the rule of law and gender issues, entrusted to the

166 Annex II (6) Bonn Agreement.

167 Report of the Secretary-General, The situation in Afghanistan and its implications for international peace and security, Doc. A/56/875-S/2002/278 of 18 March 2002 , para. 98.

168 Doc. A/56/875-S/2002/278 of 18 March 2002.

169 The UN's role during the interim period had been determined by Annexes II and III to the Bonn Agreement, whose language is closely mirrored in the S/RES/1401 (2002) of 28 March 2002 and the report by the SecretaryGeneral Doc. A/56/875-S/2002/278 of 18 March 2002.

170 S/RES/1401 (2002) of 28 March 2002, which defined its mandate for an initial period of twelve months, renewed since for subsequent twelve month periods in S/RES/1471 (2003) of 28 March 2003, S/RES/1536 (2004) of 26 March 2004, S/RES/1589 (2005) of 24 March 2005.

171 Doc. A/56/875-S/2002/278 of 18 March 2002.

172 Ibid., paras 97 and 98.

173 Ibid., para. 97. 
United Nations in the Bonn Agreement, which were endorsed by the Security Council in its resolution 1383 (2001);

(b) Promoting national reconciliation and rapprochement throughout the country, through the good offices role of [the SecretaryGeneral's] Special Representative;

(c) Managing all United Nations humanitarian relief, recovery and reconstruction activities in Afghanistan, under the overall authority of [the Secretary-General's] Special Representative and in coordination with the Interim Authority and successor administrations of Afghanistan."

As has already been pointed out, this mandate takes up many of the findings of the 2000 Brahimi report ${ }^{174}$ and can be seen as the first attempt by the UN to establish a fully integrated mission under the authority and leadership of the Special Representative of the SecretaryGeneral for Afghanistan. ${ }^{175}$ The mandate does not furnish UNAMA with any operational responsibility for administering any part of Afghanistan, but is rather a recognition of the Afghan authorities' ultimate responsibility for the Agreement's implementation. ${ }^{176}$ UNAMA is to co-ordinate and consult closely with the Afghan actors to ensure that Afghan priorities lead the mission's assistance efforts. ${ }^{177}$ The aim should be to increase Afghan capacity, while relying on as limited an international presence and on as many Afghan staff as possible, and using common support services where possible, thereby leaving a light expatriate "footprint". ${ }^{178}$ It is acknowledged that the fluidity of the situation might require a future revision and expansion of the mission's mandate. ${ }^{179}$ The emphasis on consultation and consent of the local authorities that serves to create a feeling of "ownership" of the reconstruction process may be a model for future peace-keeping and reconstruction operations. It may prevent some of the problems that can arise at the end of an operation characterized by a more "controlling" approach, once the local authorities are left to fend for themselves. It seems logical that progress toward developing local democratic and administrative structures is more difficult to achieve when the means employed to-

174 Report of the Panel on United Nations Peace Operations, Doc. A/55/305S/2000/809.

175 Doc. A/56/875-S/2002/278 of 18 March 2002, para. 98 (a) and (e).

176 Ibid., para. 98 (b).

177 Ibid., para. 98 (c).

178 Ibid, para. 98 (d).

179 Ibid., para. 98 (i). 
ward that end are authoritarian and imposed from the international community, not allowing local actors to be involved in the decisionmaking process and not building local capacities. ${ }^{180}$

To this end, UN agencies and the World Bank have embarked on capacity-building programs through the provision of training. ${ }^{181}$ In addition, program secretariats have been established within each ministry that are led by particular UN agencies and seconded with international staff. ${ }^{182}$ Within the government, the Afghan Assistance Coordination Authority (AACA) has been created to put in place a series of national programs that reflect Afghan priorities and that are oriented towards building the capacity of the Afghan Government, civil society and private sector. ${ }^{183}$ The AACA is to work together with UNAMA, whose role is to coordinate the functions of all the UN agencies engaged in humanitarian assistance.

Unfortunately, in practice the efforts have not been wholly satisfactory. While the government in Kabul has drafted a National Development Framework and has drawn up a National Development Budget in accordance with its responsibility for setting the planning and budgetary framework, it feels that it does not have the central role in determining policy and strategy. ${ }^{184}$ The UN sometimes appears to be operating like a parallel administration ${ }^{185}$ and while international aid for the national development budget is being tracked by the Ministry of Finance, the bulk of the external assistance to Afghanistan is still not being channeled through the national budget, ${ }^{186}$ as national sensibilities and the desire for "visibility" often trump the agreed need for integrated coordination and local ownership. Furthermore, some critics have remarked that the mandate and self-image of the UN does not correlate fully with the reality on the ground:

180 J.S. Kreilkamp, “U.N. Postconflict Reconstruction”, N.Y.U. J. Int'l L. E Pol. 35 (2002/2003), 619 et seq. (667).

181 P. Marsden, “Afghanistan: the reconstruction process”, Int'l Aff. 79 (2003), 91 and seq. (95).

182 Ibid.

183 Report of the Secretary-General of 18 March 2002, Doc. A/56/875S/2002/278, para. 15.

184 Marsden, see note 181, 94, 95.

185 Ibid., 95.

186 Report of the Secretary-General, Doc. A/59/581-S/2004/925 of 26 November 2004, para. 47. 
"Although Lakhdar Brahimi, the UN Special Representative for Afghanistan and head of the United Nations Assistance Mission for Afghanistan (UNAMA), ${ }^{187}$ promised a 'light footprint' in terms of international presence, based on lessons learned from East Timor, in practice there has been an extremely heavy footprint in Kabul and an extremely light (to the extent of being barely visible) footprint outside the capital". ${ }^{188}$

This has not only had a negative effect on the effectiveness of the international effort, but has also created ill-feelings among the Afghan population excluded from the benefits associated with the international presence, particularly in the Pashtun South and South-East. Related negative effects are the dislocations and market distortions that inevitably accompany the presence of a relatively large number of expatriate staff with commensurate needs and purchasing power. A distinct, but related criticism has been the extreme discrepancy in the salaries and remuneration packages earned by expatriate staff that only seldom translates into commensurate benefits for the local administration. ${ }^{189}$

\section{Instruments of the Bonn Process}

\section{Interim Authority and Emergency Loya Jirga}

One of the prerequisites for building a peaceful and stable state is the legitimacy of the government in charge of the peace-building processes. The Afghan authority that the international community first worked with was the Interim Authority under the chairmanship of Hamid Kar-

187 SRSG Brahimi's term ended on 31 December 2003, he was succeeded by Jean Arnault as SRSG, endorsed by S/RES/1536 of 26 March 2004.

188 Goodhand, see note 26, 169.

189 This is due in no small part to the inherent nature of providing external expertise to particular sections of the administration engaged in lowspecificity, high-transaction-volume activities. See F. Fukuyama, "Why there is no Science of Public Administration”, Journal of International Affairs 58 (2004), 189 et seq. Whether the criticism leveled by Afghans such as Bachardoust and others, namely that the expertise supplied is sub-standard yet overpaid needs to be assessed in this light as well, throwing up questions about the wisdom of providing certain kind of expatriate expertise. Compare “Geldmaschine Afghanistan”, Der Spiegel of 26 March 2005, 116 et seq. 
zai, ${ }^{190}$ a body whose composition had been negotiated during the talks in Bonn. ${ }^{191}$ To remedy the problem that the members of the Interim Authority lacked a public mandate, the Bonn Agreement previewed the convention of an Emergency Loya Jirga within six months of the formation of the Interim Authority to establish a Transitional Authority, including a broad-based transitional administration. ${ }^{192}$

The Emergency Loya Jirga had three tasks: choose the head of state, determine the structure of the Transitional Authority and approve the key personnel that was to lead Afghanistan for a maximum of two years until elections could be carried out. ${ }^{193}$ Although the Bonn Agreement enjoys a measure of legitimacy and is broadly accepted as an agreement negotiated in good faith, the Afghan Interim Authority created by the Bonn Agreement was viewed to be less than representative. ${ }^{194}$ Many Afghans believed that the Emergency Loya Jirga, which convened in Kabul from 11-19 June 2002, would replace the Afghan Interim Authority with a more broad-based successor administration. Unfortu-

190 Reflecting the disagreement over the role of the king in the process, Section III (2) mentions that the chairmanship over the Interim Administration had been offered to the former king but that he had declined the offer. The honorific title "Father of the Nation" bestowed by the Emergency Loya Jirga on the former king largely served the same purpose of bridging the differences between those who had advocated a return to the monarchy, and those in favor of a republican set-up. Article 158 of the new Afghan Constitution confirms the grant of this title for the lifetime of former king Mohammad Zahir Shah.

191 Section III Bonn Agreement. Its preliminary composition has been laid down in Annex IV to the Bonn Agreement. Its main features are a very large cabinet-style composition containing 30 members, including a Chairman, 5 Vice-Chairpersons who simultaneously preside over individual Departments, as well as 24 Heads of Department, corresponding to the envisaged structure of ministries. The large number of portfolios as well as vice-chairpersonships stems from the desire to include as many political and military actors as possible within the formal process, thus reducing the incentive for potential spoilers to disrupt the peace process by giving them a personal stake in it. Five departments were not filled in Bonn, thus allowing for a certain flexibility to include others who were not present or represented during the negotiations.

192 Section I (4) Bonn Agreement.

193 Section I (4) and Section IV (5) Bonn Agreement.

194 C. Johnson et al., Afghanistan's political and constitutional development, Report of the Overseas Development Institute, January 2003, 12, 13, $<$ www.odi.org.uk/hpg/papers/evaluations/afghandfid.pdf $>$. 
nately, both the process - which was not transparent - and its result fell short of the standards of legitimacy and representativeness that many had hoped for:

"The Emergency Loya Jirga did not meet the expectations of many Afghans, who hoped to elect a more representative government in addition to the president. Some delegates and electors were intimidated or pressured by leaders who retained personal control over militias and who distributed massive funds from foreign sources or illicit activities". ${ }^{195}$

The Special Independent Commission for the Convening of the Emergency Loya Jirga ${ }^{196}$ mandated with its preparation produced unclear procedural rules and, in violation of the Bonn Agreement, ${ }^{197}$ released these only one day before the commencement of the Emergency Loya Jirga. ${ }^{198}$ The participants were thus not given the opportunity to familiarize themselves with the process, resulting in several days without an agenda, chaotic speakers' lists and delegates not knowing what, when or how to decide issues. ${ }^{199}$ 1,051 of the delegates, who represented a diverse mixture of all political, religious and ethnic groups in Afghan society, were elected nationwide by 15,000 electoral persons, who had themselves been elected within their districts. ${ }^{200}$ This group was supplemented by 550 delegates appointed to ensure representation of weaker sections of society, such as refugees, women, minorities, nomads and handicapped persons. ${ }^{201}$

However, this process was not entirely free of intimidation and violence. ${ }^{202}$ The requirement of the Bonn Agreement ${ }^{203}$ that armed factions

195 B.R. Rubin et al., Building a New Afghanistan: The Value of Success, the Cost of Failure, Center for International Cooperation, NY University, 2004, 22 et seq.

196 Section IV Bonn Agreement.

197 Section IV (3) Bonn Agreement had stipulated that the Commission would publish and disseminate the rules and procedures of the convening of the Emergency Loya Jirga at least ten weeks before its commencement.

198 C. Johnson et al., see note 194, 15.

199 Ibid.

200 J. Vergau, "Manifest der Hoffnung: Über die neue Verfassung Afghanistans”, VRÜ 37 (2004), 465 et seq. (469).

201 Ibid., 469, 470. The final number of female delegates was 160.

202 For details see Human Rights Watch Briefing Paper, Afghanistan: Return of the Warlords, June 2002, 10, <http://www.hrw.org/backgrounder/asia/ afghanistan/warlords.htm>. 
should be withdrawn from Kabul was not implemented. ${ }^{204}$ Some outspoken candidates required protection, others could not return home due to personal threats made against them for their performance during the Emergency Loya Jirga. In addition, some of the 1,600 delegates were perceived to be appointed by various warlords and power brokers $^{205}$ or were themselves ${ }^{206}$ serving as military commanders and/or were accused of being complicit in human rights violations, both of which would have been criteria for ineligibility under the agreed upon procedure. While Hamid Karzai was elected as the head of the Afghan Transitional Authority ${ }^{207}$ by an overwhelming majority, and while his acceptability for office was not contested and has now been confirmed by the elections held in September 2004, this success was slightly tainted by the fact that President Bush's envoy to Afghanistan, Zalmay Khalilzad, reportedly pressured the former Afghan king Mohammed Zahir Shah to withdraw his nomination in favor of Karzai. ${ }^{208}$ In addition, the secret ballot, which was used for the election of the transitional presidency, was abandoned for votes concerning the arrangement of the transitional government and its key personnel. ${ }^{209}$ There was no debate or proper vote on the composition of the next administration or on any plan or proposal for the design of the government. ${ }^{210}$

A number of key cabinet figures confirmed by the Emergency Loya Jirga are believed to be responsible for war crimes and are deemed unacceptable by many Afghans. ${ }^{211}$ The fact that the international community deals with these individuals across a wide range of civilian issues, despite the fact that the rules of the Emergency Loya Jirga excluded their eligibility for public office, serves to accord them a legitimacy that

203 Annex I. 4. Bonn Agreement.

204 Especially a large number of troops loyal to defense "minister" Fahim continues to remain in the city until today.

205 A. Saikal, “Afghanistan after the Loya Jirga”, Survival 44 (2002), 47 et seq. (48).

206 Examples are General Dostum (deputy defense minister in the Interim Authority and a regional leader of the north of Afghanistan), Gul Agha Sherzai (the governor of Kandahar), Haji Abdul Qadir (the governor of Nangahar), and Ismail Khan (the governor of Herat).

207 The name was later changed to Transitional Islamic State of Afghanistan.

208 Saikal, see note $205,48$.

209 HRW Report, see note 202, 10.

210 Ibid.

211 Johnson et al., see note 194, 1. 
many Afghans find offensive. ${ }^{212}$ This has implications not only for the security, but also for the ability of the state to raise revenue, and for broader perceptions of legitimacy. ${ }^{213}$

Nonetheless, it cannot be denied that despite all the problems, the Emergency Loya Jirga was the first moderately democratic forum in which differences could be aired and women were given the opportunity to participate in building the foundations for future democratic processes. It did not end in a deadlock or in violence, a result that would not have come as a surprise to many observers. In light of the last 23 years of warfare and lack of public participation in governmental processes on the state level, the Loya Jirga represents a traditional Afghan mechanism that is largely accepted and respected by the Afghan people, giving them a much stronger sense of ownership of the reconstruction process than an imposed UN transitional administration could ever have done.

\section{Constitutional Process}

The next step towards permanent institutions, as outlined by the Bonn Agreement, ${ }^{214}$ was the convening of a Constitutional Loya Jirga within 18 months of the establishment of the Afghan Transitional Authority in order to adopt a new constitution for Afghanistan. To prepare the way, a nine-member Constitutional Drafting Commission was appointed on 5 October 2002, which developed a plan for the constitution-making process and a draft constitution. The Constitutional Drafting Commission, which was made up of technical drafters rather than political actors, ${ }^{215}$ passed on their results to the 35 members of the Constitutional Review Commission. ${ }^{216}$ The draft of the Constitutional Review Commission was finally passed to the Constitutional Loya Jirga that

212 Ibid., 13, also fn 34.

213 Ibid., 12, 13.

214 Section I (6) Bonn Agreement.

215 Johnson et al., see note 194, 15.

216 For a comprehensive overview of the constitutional process including the relevant documents and drafts, refer to the comprehensive website of the Constitutional Commission, <www.constitution-afg.com $>$. 
adopted the new Constitution ${ }^{217}$ on 4 January 2004. It became operative once Karzai had signed it on the 26 January 2004.

\section{a. The Drafting Process}

The drafting process itself was characterized by heated discussions between reformers and more conservative political and religious actors. ${ }^{218}$ The resulting draft draws on the substantive content of past Afghan constitutions, ${ }^{219}$ but offers a modern legal framework for the reconstruction and the establishment of the rule of law.

Unlike the constitutional drafting processes in some other war-torn countries, such as Bosnia-Herzegovina, ${ }^{220}$ where there were strong foreign influences, the drafting of the new Afghan constitution was an

217 A link to the text of the Constitution is available at: $<$ http://www.idlo.org/ AfghanLaws/Laws\%201921_todate.htm>.

218 Vergau, see note 200, 471 et seq.

219 Previous constitutions were: 1747-1923 “customary constitution"; 1923 first written constitution under Amanullah, whose reformist and secular outlook led to widespread revolt and the removal of the king; 1931 constitution under Nader Shah, which largely retracted the liberal advances and re-established the role of religion; the 1964 constitution, considered quite modern and liberal, drafted as the result of the "Palace Revolution" of $\mathrm{Za}$ her Shah who had dismissed his prime minister (and cousin and brother-inlaw) Daoud the previous year and re-asserted royal power under prime minister Dr. Yousouf; in 1973 Daoud then toppled the king and proclaimed the republic, leading in 1977 to the first republican constitution; after the Communist coup d'état of 1978 and the Soviet invasion one year later a Constitutional Declaration was proclaimed in 1980 , followed by a full constitution in 1987; in an effort to appease the opposition, the Najibullah government issued a Constitutional Revision in 1990; the 1992 Peshawar Accords effectively abrogated this constitution and established the Islamic State of Afghanistan, which can thus be considered a constitutional document in its own right, containing relatively detailed provisions about the structure of the government; in 1993 a draft for an Islamic Constitution was commenced under President Mujaddidi, and finalized as the Basic Principles of the Islamic State under Rabbani, but never formally adopted; the Taliban who came to power in 1996 likewise never adopted a formal constitution. For a comprehensive treatment see Bachardoust, see note 53; Moltmann, see note 50; Vergau, see note 200.

220 E. Sarcevic, "Völkerrechtlicher Vertrag als Gestaltungsinstrument der Verfassunggebung: Das Daytoner Verfassungsexperiment mit Präzendenzwirkung?”, AVR 39 (2001), 297 et seq. (299 and seq.). 
overwhelmingly "Afghan" process. A strong indicator is the fact, that the text was originally drafted in Dari while the UN had to provide unofficial English translations for its own use and that of the international experts permitted to see the draft at a later stage. ${ }^{221}$ The Constitutional Drafting Commission ${ }^{222}$ developed this first text mainly on the basis of the constitution of 1964, but also incorporated some aspects of the newer constitutions of 1977, 1987 and 1990.223 This first draft was then given to the Constitutional Review Commission, ${ }^{224}$ which in turn reviewed the text and showed it to a few international experts and the government's National Security Council. ${ }^{225}$

The Constitutional Review Commission worked closely together with only three foreigners: Barnett R. Rubin of the United States of America, Yash Pal Ghai of Kenya and Guy Carcassonne of France. 226 Many more international experts offered advice on specific issues, 227 such as the role of Islam, the options of a Constitutional Court for Afghanistan, the unitary versus the federal state structure option, the advantages and disadvantages of a presidential, parliamentary or mixed system, the division of powers between the executive and the legislature as well as women's rights, to name but a few. However, while the UN insisted on introducing a measure of public consultation in the drafting process and Brahimi saw the UN's role as assuring that the constitution would create a "workable" form of government and conform to basic international standards, ${ }^{228}$ foreign technical assistance was kept to a minimum because of concerns that the Constitution would appear to be

221 See B.R. Rubin, "Crafting a Constitution", Journal of Democracy 15 (2004), 5 et seq. (note 3 on page 19).

222 For a detailed documentation of the process see Secretariat of the Constitutional Commission of Afghanistan, The Constitution-Making Process in Afghanistan, Constitutional Commission of Afghanistan, 2003, <www. constitution-afg.com/drafting_comm.html>.

223 See in detail Vergau, see note 200, 467 et seq. Vergau in particular laments the failure to draw upon the more progressive elements of the 1978, 1980, 1987, and 1990, instead relying almost exclusively on the 1964 constitution.

224 A list of the members of the Constitutional Review Commission can be found at: <www.constitution-afg.com/review_comm.html>.

225 See Rubin, see note 221, 10.

226 Ibid, note 2 on page 19.

227 Some of the papers presented to the Commission are available under: $<$ www.cic.nyu.edu/conflict/conflict_translations.html>.

228 See Rubin, see note 221, 10. 
written by non-Afghans. ${ }^{229}$ Nonetheless, a UNAMA Constitutional Commission Support Unit was created that, with the agreement of the Transitional Islamic State of Afghanistan and the Secretariat, had the primary responsibility for coordinating international technical and financial support for the Project. ${ }^{230}$ UNDP was to assist the constitutional process by providing financial management, administrative and operational support. ${ }^{231}$ To increase legitimacy among Afghans, the Secretariat of the Constitutional Review Commission developed a public consultation strategy. ${ }^{232}$

By way of written submissions, oral submissions and questionnaires, input was to be collected from the public over a period of two months in all 32 provinces and from the refugees in Iran and Pakistan. Among others, issues such as the role of religion, national unity, official languages, protection of minorities, the type of governmental system, separation of powers, qualifications for public office, the Loya Jirga mechanism and more were to be addressed. In addition, the Afghan people were invited to bring up any other issue they believed should be considered in the constitutional drafting process. ${ }^{233}$ To help in this process, the UN and NGOs provided personnel and training courses. The objective was to educate selected community leaders in basic constitutional issues necessary to carry out the consultation process and to enable them to train others for this process. ${ }^{234}$ In view of the widespread rate of illiteracy, the short time-span previewed for this public consultation exercise and the limited resources, as well as the effectiveness of this process can be criticized. ${ }^{235}$ While the theory of the consultation process was commendable, in practice it did not function as expected due to a number of factors, including planning deficits by

229 ICG Asia Report No 56, Afghanistan's flawed constitutional process, 12 June 2003, 15, <http://www.crisisgroup.org/home/index.cfm?id=1639\& $\mathrm{l}=1>$.

230 F. Wardak, The Management of the Constitution Making Process in Afghanistan, Constitutional Review Commission, 1 et seq. (5), <http:// www.constitution-afg.com/resrouces/First\%20article.doc>.

231 Ibid.

232 Secretariat Constitutional Review Commission, Public Consultation Strategy, <http://www.cic.nyu.edu/conflict/conflict_translations.html>.

233 G.R. Roashan, Afghan Constitution Building Exercise, Taking the Case to the People, 5, 6, <http://www.cic.nyu.edu/conflict/conflict_translations. html>.

234 Ibid., 5.

235 Ibid., 5, 6. 
UNAMA. ${ }^{236}$ The actual draft of the constitution - with the changes incorporated at every stage of the drafting process - was not published during the consultation process, and was finally made public on 3 November 2003, barely a month before the scheduled opening of the Constitutional Loya Jirga that was to finalize the draft. ${ }^{237}$

\section{b. The Constitutional Loya Jirga}

The Constitutional Loya Jirga, however, was more successful than expected. Security and organization did not pose as many problems as during the Emergency Loya Jirga and debates over important issues did take place. ${ }^{238}$ The Secretariat of the Constitutional Commission prepared a very detailed framework for the Constitutional Loya Jirga, which reflected the legal framework laid down in a Presidential Decree of 24.04.1382 (15 July 2003) and which laid out in detail the necessary criteria for the selection of candidates, the timeline for consultations with the society and registration of candidates, the election and the roles and responsibilities of delegates, as well as the necessary interaction with international agencies that helped in the preparation of the assembly. 239

The final draft of the Constitution was presented to the Constitutional Loya Jirga that convened on 14 December 2003, consisting of 502 delegates, of which the majority was elected and about 50 were appointed. ${ }^{240}$ Among others, 64 female delegates, i.e. two from each province, 24 delegates representing the refugees in Pakistan and Iran, 9 delegates representing the nomads, and 3 delegates representing the Hindu and Sikh minorities were elected by the groups they respectively repre-

236 ICG Asia Report No. 56, see note 229, 15-20.

237 Rubin, see note 221, 10.

238 For details concerning the debated issues see Rubin, see note 221, 5 et seq. and Vergau, see note 200.

239 See the "Constitutional Loya Jirga Framework", <http://www.unamaafg.org/docs/docs.htm>.

240 For the details concerning the convention and procedures of the Constitutional Loya Jirga, see the Presidential Decree on the Convening of the Constitutional Loya Jirga of 15 July 2003, the Rules of Procedure, and the official Afghan "Draft Constitution Fact Sheet", <www.unamaafg.org/docs/docs.htm>. 
sented. ${ }^{241}$ The President appointed the rest, of whom 25 were to be legal experts and 25 were to be women. ${ }^{242}$

In addition, the following people participated as observers: cabinet members (33), the Chief Justice, members of the Constitutional Review Commission (35), the Chairpersons of the Independent Human Rights Commission and the Judicial Reform Commission. Apart from these observers the following people were ineligible: governors, deputy governors, district administrators, or mayors; staff members of the Secretariat of the Constitutional Commission; employees of the police, armed forces, and the National Security Directorate. ${ }^{243}$

There were some reports about voter and candidate intimidation, ${ }^{244}$ and this has been acknowledged even by insiders sympathetic to the process: "Afghanistan was and is not a place where a show of hands at a meeting can decide who will hold power". ${ }^{245}$ Given the clear inability of the Karzai government to assure security for voters and candidates, the government and the UN thus considered it best to keep the content of the constitutional deliberations confidential until a thoroughly vetted text could be presented to the public and the delegates to the Constitutional Loya Jirga. ${ }^{246}$ Clearly, this approach compromises normative standards of democratic participation and notions of popular sovereignty, but it can be argued that it was defensible given the danger of the process being "hijacked" by radical agendas. ${ }^{247}$ Nevertheless, the debates at the Constitutional Loya Jirga were extremely spirited with most substantive debate focusing on the choice between a purely presidential or a mixed system with a president and a prime minister ${ }^{248}$ rely-

241 Vergau, see note see note 200, 469.

242 Ibid.

243 The Secretariat of the Constitutional Commission, Framework for the Constitutional Loya Jirga, see note 239.

244 See for instance the open letter by Human Rights Watch sent to President Karzai on 29 October 2003 to this effect, <hrw.org/press/2003/10/ afgnaistan102903-ltr.htm > (NB! the spelling mistake in the URL is intentional).

245 Rubin, see note $34,8$.

246 Ibid.

247 The normative debate that arose in the context of the aborted electoral victory of the Algerian Islamicist Front Islamique du Salut (FIS) is comparable to the dilemma posed here.

248 The first option was strongly advocated by the Pashtun delegates whose ethnic majority status gave them a natural monopoly over the post of president; for the same reason the other ethnic groups strongly opposed a 
ing on a parliament-approved cabinet; the question of dual citizenship for cabinet ministers, i.e. the role returning diaspora Afghans were to play in the future; ${ }^{249}$ the place of Islam in the legal system and the denomination of the country as an Islamic Republic; as well as the position of minorities and women.

\section{c. The Constitution}

The Constitutional Loya Jirga adopted the 162 articles of the Afghan Constitution on 4 January 2004. The result is a constitution establishing a presidential system with a bicameral parliament, a highly centralized administration, strong minority rights ${ }^{250}$ including rights for minority languages and a comprehensive catalogue of human rights. A federal option had been debated, ${ }^{251}$ but was abandoned for a number of rea-

purely presidential system as a recipe for ethnic domination. The Northern Alliance, and in particular the Shura-yi Nazar within it, resisted the push towards presidentialism, but in the end its two leading figures, defense minister Fahim and education minister Qanooni, took different positions due to diverging personal ambitions. The former aspired to become sole vice-president under Karzai while the latter claimed the prospective premiership. The Americans strongly favored a strong presidency because they considered it to be a more stable form of government, thereby assuring them of a reliable point of contact. Most of the last minute changes to the draft prior to its publication concerned precisely this debate over presidentialism vs. parliamentarism. See Rubin, see note 34, 10 et seq.

249 At the time it most concerned the American-Afghan finance minister Dr. Ashraf Ghani and interior minister Ali Ahmad Jalali. The compromise worked out at the time of the adoption of the constitution, namely that parliament (the House of the People) can opt to approve a candidate despite his foreign citizenship did not help those ministers nominated by Karzai after his election in 2004 because there is as yet no parliament to approve them under article 72 (1). A number of senior officials have refused to serve as ministers due to this constitutional requirement that under the present circumstances would have required them to renounce their adopted citizenship. Personal communication with senior Afghan officials, February 2005.

250 J. Desautels-Stein, "Rites and Rights in Afghanistan: The Hazara and the 2004 Constitution", The Fletcher Forum of World Affairs 29 (2005), 157 et seq.

251 Inter alia: O. Zakhilwal, "Federalism in Afghanistan: a recipe for disintegration", Federations, special issue on Afghanistan, Oct. 2001, 11 et seq.; D. Cameron, "Overview: A role for federalism in Afghanistan after the Taliban, Federations, special issue on Afghanistan”, Federations, special issue on 
sons. While some believed it would solve some of the problems caused by warlords and ethnic divisions, ${ }^{252}$ others said that the prerequisites for a successful federal system were not given at the time of the drafting of the constitution. ${ }^{253}$ The argument brought forth most often was that Afghanistan needs a strong central government because federalism would lead to disintegration: ${ }^{254}$

"[I]n a country like Afghanistan, where illiteracy is abundant, the economy is in shambles and land and other natural sources are not evenly distributed across the country, federalism would lead to warlordism, personal fiefdoms, no respect for the central government and a continuation of internal war - this time over who gets what". 255

Another argument against a federal solution was the fear of more interference in Afghan affairs from the neighboring countries, especially as the Iran-backed Hezb-i-Wabdat of Khalili and the Uzbekistan- and Russia-backed Junbish-i-Mili of General Dostum called for federalism. ${ }^{256}$ In response to these fears, article 1 of the Afghan Constitution now reads "Afghanistan is an Islamic Republic, independent, unitary

Afghanistan, Oct. 2001, 3 et seq.; R. Chowdhari Tremblay, "A federal arrangement for Afghanistan”, Federations, special issue on Afghanistan, Oct. 2001, 9 et seq.; H.E. Hale, The Federal Option for Afghanistan, East West Institute, Policy Brief Vol. 1, No. 7, November 2002, $<$ www.ewi.info/pdf/volume1_issue7.pdf>; G.R. Roashan, Pros and Cons of Federalism in Afghanistan, Institute for Afghan Studies, <www.institutefor-afghan-studies.org/AFGHAN\%20CONFLICT/Analsis/

Pros\%20and\%20Cons\%20of\%20Federalism\%20in\%20Afghanistan.pdf >; Y.P. Ghai, An Options Paper for the Afghan Constitution Commission, Unitary or Federal: A False Choice? Decentralisation of state powers in Afghanistan, Center on International Cooperation, <www.cic.nyu.edu/pdf/ E5DencentralizationofPowerGhai.pdf >; H. Malikyar/ B.R. Rubin, CenterPeriphery Relations in the Aghan State: Current Practices, Future Prospects, Center on International Cooperation, December 2002, 1 et seq., $<$ http://www.cic.nyu.edu/pdf/CPReport0107031.pdf >.

252 Hale, see note 251, 1, 6, 7; Cameron, see note 251, 4; Tremblay, see note 251, 10.

253 Roashan, see note 251, 6; Malikyar/ Rubin, see note 251, 44-46.

254 Marshall Qasim Fahim, Vice President and Minister of Defense, Afshraf Ghani, Minister of Finance at the Loya Jirga, Gul Agha Shirzai of Qandahar, Hajji Din Muhammad, Governor of Nangarhar, all quoted in Malikyar/ Rubin, see note 251, 41.

255 Zakhilwal, see note 251, 12.

256 Ibid. 
and indivisible state". The head of state is a strong President, who appoints his cabinet with the approval of the National Assembly. ${ }^{257}$ In consideration of the special role Loya Jirgas as a traditional mechanism have played in decision-making processes in Afghanistan, the Constitution contains special regulations concerning the Loya Jirga "as the highest manifestation of the people of Afghanistan". ${ }^{258}$ The Loya Jirga has the competence to amend the Constitution, prosecute the President and decide on issues "related to independence, national sovereignty, territorial integrity, and supreme interests of the country". ${ }^{259}$

While the Constitution takes into consideration that there are many ethnic groups living in Afghanistan, it uses Islam as a strongly unifying factor, referring to it in many articles. ${ }^{260}$ Article 2 of the Constitution defines Islam as the religion of the state, but at the same time determines that: "Followers of other religions are free to exercise their faith and perform their religious rites within the limits of the provisions of the law." 261 Furthermore, the Constitution explicitly states that the nation of Afghanistan is comprised of the various ethnic groups, ${ }^{262}$ and allows the languages of these ethnic groups to be the third official language, next to Pashtu and Dari, in those areas where the majority speaks them. ${ }^{263}$

Discrimination of any kind is prohibited. ${ }^{264}$ This prohibition is a part of the human rights catalogue contained in Chapter Two of the Constitution that also determines the duties of the citizens. ${ }^{265}$ These rights can be enforced by the strong judiciary, headed by the Supreme Court, ${ }^{266}$ and are protected in their continuity by article 149 II Afghan Constitution that determines that " $[\mathrm{t}]$ he amendment of the fundamental rights of the people is only permitted to make them more effective". A Constitutional Court is not envisaged, the Supreme Court having the

257 See arts 60, 64, 65, 66, 71, 75, 79 of the Afghan Constitution.

258 Article 110, see also the whole Chapter 6, arts 110-115 of the Afghan Constitution.

259 Article 111 of the Afghan Constitution.

260 Arts 1, 2, 3, 17, 18, 19, 23, 35, 45, 54, 60, 62, 81, 116, 118, 130, 131, 136, 149, 159, 161, 162 of the Afghan Constitution.

261 Article 2 II of the Afghan Constitution.

262 Article 4 of the Afghan Constitution.

263 Article 16 of the Afghan Constitution.

264 Article 22 of the Afghan Constitution.

265 Articles 22-59 of the Afghan Constitution.

266 Articles 116-135 of the Afghan Constitution. 
competence to review the constitutionality of laws, legislative decrees, and international treaties. ${ }^{267}$

What influence article 3 of the Constitution, which states that: "[i]n Afghanistan, no law can be contrary to the beliefs and provisions of the sacred religion of Islam", will have on the legal reality and human rights in Afghanistan remains to be seen and will be strongly dependent on the judiciary. ${ }^{268}$ Furthermore, it needs to be pointed out that the most egregious instances of human rights violations are either the result of arbitrary violence committed by military commanders, or come about through the application of tribal law. With regard to the former it must be said that the pertained religious or secular nature of the legal system will have little impact on such abuses, as only the effectiveness of law enforcement will affect impunity and thus the prevalence of violations.

With regard to tribal law, however, it can be argued that classical Islamic law with its very strict procedural safeguards and clear stipulations and rights regimes, for instance in family and personal status law, would actually constitute a progressive advance in rights protection. This is not an apologetic argument about the perceived compatibility of Islamic law with international standards, which we think cannot be maintained. Yet, compared to the legal reality dominated by tribal law, a significant progressive potential for Islamic law cannot be doubted. ${ }^{269}$

The lack of an explicit reference to the Shari'a or a specific school of Islamic $\mathrm{law}^{270}$ in art. 3 of the constitution allows the assumption that

267 Article 121 of the Afghan Constitution.

268 R. Wolfrum/ E. Afsah, Stellungnabme zum afghanischen Verfassungsentwurf, Max Planck Institute for Comparative Public Law and International Law of 4 November 2003.

269 Ibid. For concurring views see Vergau, see note 200; Toscano/ Drury, see note 5 .

270 Article 130 stipulates that for filling lacunae of the law, the judiciary should have recourse to the jurisprudence of the Hanafi school. This has been justly hailed as a major departure from previous practice where Hanafi jurisprudence was effectively treated as the law of the land; as it is in fact the case in many other Islamic countries which stipulate the exclusive validity of the respectively dominant school (there are altogether six orthodox schools, each completely separate, but equally valid; on the concept of multiple simultaneous orthodoxies see J. Schacht, An Introduction to Islamic Law, 1964). The fact that different Muslim congregations follow different schools of law, and that there is no normative hierarchy between them is an entirely uncontroversial proposition among students of figh (Islamic jurisprudence). For essentially political reasons, namely a subverted version of 
the authors of the Constitution aimed at confirming the Islamic character of the state, rather than binding the state organs to the Shari'a. The final text of the constitution is a modern constitution that is in conformity with international human rights standards and which provides a legal structure that will aid the reconstruction process in Afghanistan.

\section{Elections}

After the new Constitution had been passed, the Bonn Agreement previewed that by June 2004 presidential and parliamentary elections would end a two and a half year political transition process. ${ }^{271}$ The transitional regulations contained in the new constitution ${ }^{272}$ define the end of the transitional phase as the point in time in which the new $\mathrm{Na}$ tional Assembly is inaugurated. In view of the many prerequisites to a parliamentary election, such as developing the complete legal framework for these elections, completing the first population census in 25 years necessary to determine the number of National Assembly seats in each province as well as provincial and district council membership, demarcation of district boundaries, registration of eligible voters, public

the Jacobin nation-state grafted upon notions of the Islamic identity of the nation, coupled with perceived necessity to prevent legal pluralism derived from the civil law tradition, many Islamic states have traditionally attempted to legislate the exclusive validity of any one school at the expense of all the others. Needless to say, such attempts have been extremely unpopular with followers of minority denominations, both because it was perceived to be discriminatory but also because on dogmatic grounds such measures are difficult to defend due to the hierarchical equality of all schools in classical figh. Article 131 has in this context been hailed as a major breakthrough, not only in Afghan legal tradition but compared with other regional constitutions. It stipulates essentially the validity of Shiite personal status law for disputes involving members of that minority, as well as referring to Shiite jurisprudence in cases of lacunae in the law. There is some debate about the relationship between article 130 and 131, in particular the extent to which the two are self-executing, and whether article 131 applies only after recourse to Hanafi jurisprudence according to article 130 has yielded no satisfactory result, or whether in the case of a lacuna recourse should directly be had to Shiite jurisprudence. The resolution of these questions is difficult to discuss in abstracto, and needs to be seen in the light of future stance taken by the Afghan judiciary.

271 Section I Bonn Agreement.

272 Article 159 of the Afghan Constitution. 
awareness campaigns, the formation and registration of political parties, and more, it did not come as a surprise that the presidential and parliamentary elections ${ }^{273}$ were not held at the same time as had originally been planned. ${ }^{274}$ Instead, it was decided to hold presidential elections at an earlier stage because by their nature they were easier to organize and conduct, as no political parties or large numbers of local candidates needed to be managed. Furthermore, President Karzai had made it clear that he was not willing to stay over the period previewed by the Bonn Agreement, an understandable choice given Afghanistan's modern experience. ${ }^{275}$ It was therefore decided to hold parliamentary elections at a later date. It is only with the successful election and inauguration of the National Assembly that the transitional period laid down in the Bonn Agreement will come to an end, thereby also ending a period marked by the absence of a real separation of powers - a problem that many transitional governments are faced with.

\section{a. Presidential Elections}

Before the Presidential elections actually took place on 9 October 2004, the UN carried out a voter registration exercise which resulted in the registration of 10.5 million Afghans. ${ }^{276}$ Pursuant to the Afghan request for assistance regarding the preparation, organization, conduct and supervision of the first electoral process, yet with regard to the light footprint approach, the elections were organized by the Joint Electoral Monitoring Body (JEMB), a joint commission made up of international experts and the Interim Afghan Electoral Commission. ${ }^{277}$ The JEMB

273 Report of the Secretary-General, The situation in Afghanistan and its implications for international peace and security, Doc. A/58/868-S/2004/634 of 12 August 2004, para. 8 and Annex.

274 Section I (4) Bonn Agreement and article 116 II of the Afghan Constitution.

275 For instance Rabbani's refusal to honor the Peshawar Agreement.

276 Report of the Secretary-General, The situation in Afghanistan and its implications for international peace and security, Doc. A/59/581-S/2004/925 of 26 November 2004, paras 5,6.

277 Presidential Decree No. 40 on the Establishment of the JEMB of 26 July 2003, amended by Presidential Decree No. 110 on Arrangements for Holding Elections during the Transitional Period of 18 February 2004, $<w w w . j e m b . o r g / e n g / l e g i s l a t i o n . h t m l>$. The international experts on the JEMB were appointed by the UN Special Representative of the SecretaryGeneral for Afghanistan. 
momentarily exercises all the functions later reserved for the Independent Electoral Commission, but its functions will lapse upon the end of the transitional period. ${ }^{278}$

Many observers believed the election time-table established by the Bonn Agreement was far too ambitious ${ }^{279}$ and that the lack of security throughout the country would prevent successful elections. Some believed that even if the elections were formally successful, they may be devoid of meaning in the sense that they may not reflect the realities of power and authority, and thus may not result in a stable and sustainable government. ${ }^{280}$ Now the results of the presidential election give hope that the parliamentary election will also be more successful than expected. The presidential election held on the 9 October 2004 was plagued by certain logistical problems, such as the failure to mark voters with indelible ink in some polling booths, poor training of election staff, as well as incidences of intimidation. Nevertheless, an independent international team, charged by the UN with examining fraud, has certified the election's credibility. ${ }^{281}$

Part of the success may be attributed to the fact that some of the potential spoilers in the peace process, warlords with their own militias, were integrated into the official process and were given the opportunity to run as presidential candidates. There has been criticism because the international community, in the form of the international members of the JEMB mandated with examining the formal suitability of the presidential candidates, ${ }^{282}$ allowed certain individuals in command of unoffi-

278 Article 2 of the Presidential Decree No. 110 of 18 February 2004. The end of the transitional period is defined in article 159 Afghan Constitution as the date of inauguration of the National Assembly.

279 For example, ICG Afghanistan Briefing, The Afghan Transitional Administration - Prospects and Perils, 30 July 2002, <www.crisisweb.org/ home/index.cfm?id=2087\&l=1>; A. Wimmer/ C. Schetter, "Putting StateFormation First: Some Recommendations for Reconstruction and PeaceMaking in Afghanistan”, Journal of International Development 15 (2003), 525 et seq. $(535,536)$.

280 B.R. Rubin, “(Re) Building Afghanistan: The Folly of Stateless Democracy”, Current History 103 (2004), 165 and seq. (168, 170); A. Thier/ J. Chopra, "The road ahead: political and institutional reconstruction in Afghanistan”, Third World Quarterly 23 (2002), 893 (901).

281 Final Report of the Impartial Panel of Election Experts Concerning Afghanistan Presidential Election 2004 of 1 November 2004.

282 See article 6 (i) Regulations for the Nomination of Candidates for the Presidential Elections, <www.jemb.org/eng/legislation.html $>$. 
cial militias to run for President despite being formally ineligible. ${ }^{283}$ However, it can be argued that these decisions may have helped to stabilize the institution-building process. Had these individuals been excluded from the formal process, it is not improbable that they would have resorted to violence. By being allowed to run as candidates, they were given the chance to compete within the process, instead of being forced to contest it from without. Although there had been fears of attacks by anti-Government elements, no major security incidents occurred. ${ }^{284}$ This was not only due to the presence of ISAF, but also due to the successful role of the budding Afghan police force and the Afghan National Army in providing security and order during the presidential election, despite limited resources and training opportunities. ${ }^{285}$

Concerning the reflection of real power structures it can be said that this election was not merely a rubber stamp election, but that Karzai's legitimacy has been strengthened. A number of warlords previously part of the Transitional government have now been ousted and replaced by reformers and technocrats in the new cabinet sworn in by the Afghan President Hamed Karzai on the 24 December 2004. ${ }^{286}$ The appointment of some cabinet members was not uncontroversial, especially the appointment of the former governor of Herat as the new minister of energy. This has been criticized not only because his lack of qualification for the post envisaged calls into question the meritocratic nature of government service, but also because his continued control of irregular militias and his past responsibility for a variety of human rights violations is perceived to send out the wrong signals of impunity. ${ }^{287}$

Given the relative weakness of central governmental institutions, it is, however, difficult to establish how President Karzai could avoid integrating forces that may otherwise be in a position to aggravate the security situation within the country. The absence of a strong military force loyal to the central authorities in Kabul and the Afghan Constitu-

283 Article 16 (3) e) Electoral Law, <www.unama-afg.org/docs/docs.htm>, article 62 Afghan Constitution.

284 Report of the Secretary-General, Doc. A/59/581-S/2004/925 of 26 November 2004, para. 7 .

285 Ibid., 13, 21, 25.

286 BBC News, New Afghanistan cabinet sworn in, of 24 December 2004, <http://news.bbc.co.uk/go/pr/fr/-/2/hi/south_asia/4123607.stm>.

287 Human Rights Watch, All Our Hopes are Crushed: Violence and Repression in Western Afghanistan, Vol. 14 No. 7 (C), November 2002, $<$ http://hrw.org/reports/2002/afghan3/>. 
tion brings with it the necessity of appeasing and accommodating irregular power-brokers until unofficial forces have been disarmed and demobilized. In accordance with arts 161 and 71 of the Afghan Constitution, the cabinet will still have to be approved by the National Assembly once it has been elected. Until that time, Karzai and his two vice presidents are free to act without scrutiny by the National Assembly.

\section{b. Parliamentary Elections}

The parliamentary elections that were already postponed to April 2005, have once more been postponed and are now scheduled to take place on 18 September 2005, but even then the upper house will only be temporary as the necessary elections of the district councils will not take place. ${ }^{288}$ Not only do security issues have to be addressed more thoroughly, but a myriad of legal and administrative preparations are still necessary, such as the demarcation of district boundaries, the definition of the powers and responsibilities of the provincial and district councils, the education of voters and candidates about the forthcoming elections, and the preparation of facilities and legal instruments for the National Assembly and the councils.

Among other activities, the international community is helping the Afghan authorities prepare for this event through the Support to the Establishment of the Afghan Legislature (SEAL) project. ${ }^{289}$ The main actors involved are the Afghan Civil Service Commission, the French government and UNDP. This project aims to put in place the necessary stable democratic foundations for the Afghan legislature and will, inter alia, establish a secretariat to the parliament and train secretariat staff to work effectively to support the new parliamentarians, many of whom will be coming from isolated Afghan rural areas with no knowledge of or previous experience in such a body. Once the National Assembly has been inaugurated, one of the first tasks will be to review the decrees passed in the transitional phase and approve the Ministers appointed by President Karzai. ${ }^{290}$ Given the absence of a viable parliamentary tradi-

288 R. Synovitz, Afghanistan: Kabul to Create Temporary Chamber of Parliament, Radio Free Europe/Radio Liberty, 21 March 2005, $<$ www.afgha.com/ ?af=article\&sid=48253>.

289 Relief Web, UNDP and Afghan Civil Service Commission SEAL a deal for Parliament, UNDP of 22 February, 2005, <http://www.reliefweb.int/rw/ rwb.nsf/0/e98eb7e74084411e49256fb20006235f?OpenDocument>.

290 Article 161 V Afghan Constitution and article 71 II Afghan Constitution. 
tion in the country, and given the fact that the existing political parties are not based around a political program but along ethnic lines, strong apprehension exists about the functioning of the new parliament. In particular, the fact that almost all parties are linked to one or the other of the armed factions allows for the possibility of parliamentary disputes potentially spilling over into armed confrontations. There are examples of military movements transforming themselves effectively into political groupings that use the parliamentary system effectively, and are fairly loyal to the rules of the game; ${ }^{291}$ just as there are examples of political wings of military factions that survive the demise of the military struggle and become effective political parties. ${ }^{292}$ However, the question whether parliamentary norms and codes of conduct will take hold, and, more importantly, whether parliament will be able to function as an institution within the overall structure of government, i.e. beyond mere partisan identities and interests, cannot be answered at the moment.

\section{Further Obstacles to the Reconstruction Process}

As is the case in all post-conflict situations, problems arise that impede the reconstruction process. Some are specific to the given conflict and arise out of its particular history, culture, geography and society; others, in contrast, are likely to appear in all post-conflict situations. In Afghanistan, obstacles that should be pointed out are the lack of finances for the reconstruction process, the security problem arising from various factors, narcotics, transitional justice, the influx of foreigners into the capital, as well as the unresolved demobilization issue.

\section{Financial Commitments}

Until Afghanistan has surpassed its present transitional period, and long beyond that, the reconstruction process that is currently being coordinated by UNAMA will require the continued assistance of the international community, not the least in financial terms. To meet the immediate financial needs of the Interim Authority, UNDP established the Afghanistan Interim Authority Fund immediately after the conclu-

291 An arguable example could be the Hisbollab in Lebanon.

292 Shin Fein in Northern Ireland springs to mind. 
sion of the Bonn Agreement. ${ }^{293}$ The first contributions of donor countries were to be used to establish work places for the Interim Authority and to pay the salaries of the Afghan civil servants.

The donor conferences held in Tokyo in mid-January 2002 and in Berlin in April 2004 have helped define the broad outlines for peacemaking and reconstruction in Afghanistan. For the Tokyo Conference, ${ }^{294}$ UNDP, World Bank and the Asian Development Bank prepared a Preliminary Needs Assessment for Recovery and Reconstruction for 2002-2006, which included estimates of the reconstruction costs and helped prioritize funding through donor countries. At the same conference, a comprehensive Immediate and Transitional Assistance Program for the Afghan People 2002 (ITAP) was presented that had been prepared after consultations with the international community as well as Afghan and international non-governmental organizations (NGOs).

In Berlin, ${ }^{295}$ the implementation of the Bonn Agreement was evaluated in a Progress Report and the process of reconstruction was further shaped by a Work Plan of the Afghan Government. At the conference the Afghan government presented a consolidated budget based on the combined expertise of more than 100 international experts working in close consultation with the respective government organs and in cooperation with UNAMA, UNDP, the World Bank, and the Asian Development Bank. The report presented to the international donor community entitled Securing Afghanistan's Future 296 laid out the financial requirements for bringing Afghanistan along the road to sustainable recovery. The report argues that US\$27.5 billion in aid over a period of seven years will be required, including US\$ 6 billion going directly to the government budget.

Acknowledging that it would be impossible for donor governments to make that kind of financial commitment over the projected time

293 Report of the Secretary-General, Doc. A/56/875-S/2002/278 of 18 March 2002, para. 23. and 24.

294 See UN article with annex: "Donors meet in Tokyo to Commit to Major Recovery Plan for Conflict-Ravaged Afghanistan (18 January 2002)" <http://www.un.org.pk/latest-dev/hq-press-020118-1.htm>.

295 See the Berlin Declaration of 1 April 2004 with Annex <http://www. bglatzer.de/aga/berlindeclaration.pdf $>$.

296 Government of Afghanistan Ministry of Finance, Securing Afghanistan's Future: Accomplishments and the Strategic Path Forward, 2004, $<$ http://www.adb.org/Documents/Reports/Afghanistan/securingafghanistan-future-final.pdf $>$. 
frame, the Afghan government made much more modest requests: seeking an acknowledgment that success will require a sustained commitment of approximately that order of magnitude over time; a political commitment to provide about US\$ 12 billion of support over three years; and pledges of US\$ 4.5 billion for the coming year. ${ }^{297}$

These figures seem enormous if looked at in isolation, but look much more modest if compared to the financial and military efforts expended in other post-conflict situations. ${ }^{298}$ There is little doubt that despite the high political priority accorded to its reconstruction, the "level of foreign assistance Afghanistan has received so far appears to be on the low side compared to other recent post-conflict cases". ${ }^{299}$ This sentiment of the IMF is echoed by the former US Special Envoy to Afghanistan, James Dobbins, who maintains that Afghanistan is "the least resourced, large-scale American reconstruction program ever". ${ }^{300}$ If we start from the assessment contained in Securing Afghanistan's Future as a realistic estimate of the needs, then the amounts pledged by the donor community fell far short, ${ }^{301}$ especially if we take into account that the

297 Rubin, see note 195, 6.

298 The following figures can serve as an indication: East Timor (1999-2001) US\$ 256/60 per cent (Aid as percentage of GDP); Bosnia (1995-1997) US\$ 249/40 per cent; Palestine (1994-2001) US\$219/13 per cent; Rwanda (19941996) US\$ 114/61 per cent; Haiti (1995-1998) US\$ 74/16 per cent; Afghanistan (1/02-3/03, actual) US\$ 67/ 25 per cent; Afghanistan (2004-2010, projected) US\$ 182/ 62 per cent. The figures for Afghanistan are based on a population estimate of 22 million; there is some indication that the figure might be closer to 25 million, in which case the figures states would be lower still. Sources: IMF, World Bank, J. Dobbins, et al., America's Role in Nation-Building: From Germany to Iraq, 2003, quoted in Rubin, see note 195, 15.

299 International Monetary Fund, Islamic State of Afghanistan: Rebuilding a Macroeconomic Framework for Reconstruction and Growth, 2004, 16.

300 B. Duncan, "The Nation-Building that the US Neglects", al-Jazeera, <http://english.aljazeera.net/NR/exeres/F64904AC-0C00-4AAB-BDE9B38DCOE206B1.htm>.

301 For the most up-to-date figures see the Afghanistan Donor Assistance Database (DAD) online, <http://www.af/dad/index.html>. Note that Pledges (political statement of intent) do not necessarily translate fully into Commitments (actual domestic budgeting by the donor), let alone Disbursements (money actually transferred to implementing organizations or the Afghan government). Out of the latter figure, funds earmarked for Reconstruction are lower still, i.e. excluding humanitarian assistance which con- 
"bulk" of assistance has gone towards humanitarian aid which, unlike reconstruction aid, has only a marginal impact on the prospect of sustainable development. ${ }^{302}$

The costs of reconstruction appear outright miniscule in comparison to the enormous outlays for the ongoing military campaign, whether looking at the expenses of ISAF $^{303}$ or the Coalition. ${ }^{304}$ More importantly, as Rubin et al. point out, the cost of failure is prohibitive, especially if one factors in the rising cost of military and security-related expenses if the situation in Afghanistan deteriorates again to pre-2001 levels. ${ }^{305}$ They lay out three different scenarios of donor commitment, namely fulfilling the needs assessment contained in Securing Afghanistan's Future over a seven year period with much reduced funding available until 2016 and beyond; continuing the present limited engagement unchanged; and, finally, drastically reducing reconstruction aid in the next two to three years due to donor fatigue. In the latter two scenarios the likely military costs of answering the security challenge of an internally insecure Afghanistan will be prohibitive.

\section{Security and Narcotics}

Other issues that pose serious hurdles for the reconstruction process in Afghanistan are security and narcotics. A study examining civil wars found that half of the countries that settle civil wars with peace agreements revert to violence within five years. ${ }^{306}$ Two main factors are responsible: the accessibility of resources that can easily be looted or ex-

tributes little to overall development objectives. Projects Completed represent an even smaller figure.

302 This is the IMF's estimate, International Monetary Fund, Islamic State of Afghanistan: Rebuilding a Macroeconomic Framework for Reconstruction and Growth, see note 299, 16.

303 About US\$ 1.3-1.5 billion per year for maintaining 5,500 ISAF troops in Kabul. Source Securing Afghanistan's Future, see note 296.

304 The US component of the Coalition alone costs some US\$ 12 billion per year for 11,000 US troops out of a total of 13,800 . Source Rubin, see note 195, 22, referring to testimony by General John Abizaid and confirmed by the Congressional Budged Office.

305 Rubin et al., see note 195.

306 P. Collier et al., On the Duration of Civil War, 2001, <http://www. worldbank.org/research/conflict/papers/CHS_Duration.pdf $>$. 
tracted from the population through various forms of "taxes", "custom" duties, etc., and the persistence of unofficial armed formations. ${ }^{307}$

All conflicts offer certain economic incentives to some sections of the population, in particular the need of the parties to the conflict to finance the struggle often leads to the adoption of illicit but lucrative activities that can be taxed or exploited directly. ${ }^{308}$ In Afghanistan the production, processing, and smuggling of opium has fuelled the armed conflict and in the past provided an important source of revenue to armed factions protecting and taxing it, as well as the individuals directly involved with the production. While all factions engaged in the narcotics trade throughout the conflict, the vacuum left by the departure of the Taliban has led many warlords to assert control over parts of the country and to use that physical control to extract revenue.

Three related factors have led to the massive increase in opium production since 2001: first, the opium trade is by far the most lucrative activity in present-day Afghanistan, so warlords have used it as a way to collect revenue, both for personal enrichment and to pay for their militias; secondly, the central government remains unable to police the country effectively, thereby leaving the producers and traffickers with very little to fear; last, but not least, the Coalition has focused on fighting terrorist groups, diverting manpower to engage effectively in antinarcotics has been considered inexpedient; furthermore the Coalition often depends on the collaboration of the very same warlords suspected of complicity in the narcotics trade. It can likewise by no means be assumed that the members of the central government have no personal involvement in the narcotics trade. ${ }^{309}$

Given the extreme poverty of Afghanistan, and the way international aid is disbursed, income from narcotics actually constitutes an enormous percentage of GDP: combined farmers' and traffickers income from opium amounted to 52 per cent of GDP in 2002. ${ }^{310}$ Furthermore, the impressive-looking levels of international assistance pales into relative insignificance if compared with the income from drugs: aid

307 Discussed in Rubin et al., see note 195, 10.

308 Goodhand, see note 26; D. Keen, The Economic Functions of Civil Wars, 1998 ,

309 C. Gall, "Poppy Growing Reaches Record Level, UN Says", New York Times of 19 November 2004, 3, who accuses President Karzai’s brother, Ahmed Wali Karzai of complicity in the drug trade.

310 UNODC, quoted in B.R. Rubin, Road to Ruin: Afghanistan's Booming Opium Industry, Center on International Cooperation, 2004, 9. 
disbursement (as opposed to mere pledges) in the two years 2002-2003 had been US\$ 2.9 billion; in the same period the yearly income from drugs was US\$ 2.3 billion. The figures become even more alarming if we keep in mind that a very large percentage of the foreign aid is spent on overheads, consultancy salaries, etc. and thus does not benefit the Afghan population directly. ${ }^{311}$ Of the annual drug money, in contrast, about US\$ 1 billion goes directly to the farmers, and the remaining US\$ 1.3-1.5 billion to those power holders that compete with the government institutions in the provinces. ${ }^{312}$

The danger of narcotic production becoming endemic and eventually subverting the establishment of institutions is palpable and has, if anything, grown in recent years. Several high-ranking officials have been warning about the creation of a "narco-state" 13 dominated by violence, an illegitimate economy, and with all the negative domestic and international implications that might occur. The present production figures are nothing short of catastrophic, with Afghanistan producing an estimated 87 per cent of the world's opium. ${ }^{314}$

\section{The Afghan Independent Human Rights Commission and Transitional Justice}

In the course of reconstruction and rehabilitation a question that will also have to be addressed is not only the amelioration of the still worrying human rights situation, but also the issue of post-conflict justice. Over three decades, the Afghan people have had to suffer severe human rights violations: summary executions, elimination of political opponents, torture, suppression of minorities, forced marriages with Taliban

311 B.R. Rubin, et al., Through the Fog of Peace Building: Evaluating the Reconstruction of Afghanistan, Center on International Cooperation, 2003, 27 et seq.

312 Rubin, et al., see note 195, 17, the figures are based on UNODC's annual Afghanistan Opium Survey.

313 See remarks by US ambassador Zalmay Khalilzad, quoted in V. Burnett, "Crackdown on Afghanistan's Crash Crop Looms: In war on drugs, authorities seek to uproot poppies”, Boston Globe of 27 September 2004, likewise remarks by Antonio Maria Costa, head of UNODC, quoted in Gall, see note 309 .

314 Ibid. See also official UNODC figures in Afghanistan Opium Survey 2004, $<$ www.unodc.org/afg/en/reports_surveys.html>. 
fighters, rape, murder and more. ${ }^{315}$ The Commission on Human Rights has emphasized the necessity of developing a strategy to support the victims of political violence to come to terms with their past. ${ }^{316}$

Generally, options could include a Truth and Reconciliation Commission, the prosecution of war criminals, financial compensation, educational measures, sanctions of a non-penal character, as well as general institutional reforms. ${ }^{317}$ Both the new Constitution and the Bonn Agreement lack norms that could form a legal framework for the development and implementation of a strategy for transitional justice. However, the Presidential Decree of 2 June 2002 on the Establishment of the Afghan Independent Human Rights Commission (AIHRC) states that the AIHRC "shall as well undertake national consultations and propose a national strategy for transitional justice and for addressing the abuses of the past." 318 The positive aspect to be seen in the lacunae of legal instruments to address this issue is the fact that amnesties for war criminals or other factors hampering transitional justice arrangements are not envisaged. ${ }^{319}$

The AIHRC, which is presently the only institution that is seriously engaged with this issue, is to function in accordance with the "Paris Principles", contained in the annex to A/RES/48/134 of 20 December

315 Only exemplary: Report of the Independent Expert of the Commission on Human Rights in Afghanistan, Doc. A/59/370 of 21 September 2004, 8,9; M.A. Drumbl, "Rights, Culture, and Crime: The Role of Rule of Law for The Women of Afghanistan”, Colum. J. Transnat'l L. 42 (2004), 349 et seq. (354-359).

316 Report, see note 315, 23, 24.

317 Ibid.

318 "Decree of the Presidency of the Interim Administration of Afghanistan on the Establishment of an Afghan Independent Human Rights Commission", 06/06/2002, see Annex I, article 9. The establishment of the AIHRC is provided for in article 58 of the Constitution.

319 On the question of amnesties see the account of SRSG Brahimi's intervention during the Bonn negotiations where he successfully argued against the inclusion of an amnesty clause by reference to his experiences during the Algerian war of liberation, in particular French torturers who later on published exonerating, even bragging accounts of their deeds under the protection of a blanket amnesty of the French government. See Rubin, see note 36. 
1993. ${ }^{320}$ Most importantly, the AIHRC is to fulfill its tasks independently of the government. In the field of human rights, the AIHRC is to function parallel to the formal court system and other institutions. The Constitution ${ }^{321}$ contains the right of "any person, whose fundamental rights have been violated" to file a complaint, and previews that the AIHRC can "refer cases of violation of human rights to the legal authorities, and assist in defending the rights of the complainant". The Presidential Decree mentioned above extends this mandate to include the task of actively advancing the transitional justice process.

The AIHRC was only able to commence its work six months after it had been established, and one year after the Bonn Agreement it still did not have the means to effectively do its work. ${ }^{322}$ In the meantime, the AIHRC has more than 300 employees in its offices in Kabul and the provinces. ${ }^{323}$ It has been able to begin work concerning children's rights, women's rights, human rights, and monitoring. ${ }^{324}$ Furthermore, the AIHRC has attempted the daunting task of developing a strategy for transitional justice as envisaged in the Presidential Decree of 2 June 2002. To determine which measures should be adopted to begin the process of transitional justice and aid the peace building process, the AIHRC has already completed the national consultation stipulated in its mandate. The concept of a "light-footprint approach" of the UN has also been applicable in this area, as the international community only assisted the AIHRC that for its part relied on the input of the Afghan population to develop a strategy for transitional justice. The report ${ }^{325}$ that was prepared as a result of the consultation process includes recommendations for the government, the international community and civil society. The national strategy outlined in the study was developed after holding about 200 focus group discussions with over 2000 participants and questioning 4151 random individuals in 32 provinces and

320 See in this respect article 15, Annex One of Decree of the Presidency of the Interim Administration of Afghanistan on the Establishment of an Afghan Independent Human Rights Commission, 06/06/2002.

321 Article 58 II and III Afghan Constitution.

322 HRW Report, see note 202.

323 Report, see note315, 15.

324 Report, ibid.

325 Afghanistan Independent Human Rights Commission, A Call for Justice, $A$ National Consultation on past Human Rights Violations in Afghanistan, February $2005<$ www.aihrc.org.af/>. 
refugees in Pakistan and Iran. ${ }^{326}$ The strategy encompasses non-judicial acts conveying commitment to justice, as well as the more concrete proposals of a combination of vetting, institutional reform and measures leading to individual prosecution. ${ }^{327}$

Taking into consideration both the present lack of adequate domestic capacities for complex prosecutorial or judicial proceedings, as well as the preference for trials to be held in Afghanistan, the AIHRC proposes the establishment of a Special Prosecutor's Office in two years and the establishment of a War Crimes Chamber in three years. ${ }^{328}$ Only those bearing the greatest responsibility for crimes or having committed serious crimes are to be prosecuted. ${ }^{329}$ While the majority of the participants also called for reparations and some kind of truth-seeking mechanism, a precise approach in this regard could not be articulated due to the lack of information. ${ }^{330}$ However, the AIHRC also recommends the establishment of a legal framework enabling the victims to bring civil suits against perpetrators for compensation. ${ }^{331}$ In line with the idea of Afghan ownership of the process, the role envisaged for the international community is a supportive one: the recommendations mainly focus on the need for political and financial support, technical assistance as well as expertise. ${ }^{332}$ So far this has been provided by UNAMA supporting the AIHRC in all its activities.

The hurdles that are still in place for the implementation of the confrontational aspects of such a strategy are evident. There is a glaring lack of the legal capacity that would be required to construct and implement the legal framework. Furthermore, the financial resources that would be necessary to implement any strategy of transitional justice are tremendous and, in view of the lack of priority given to this issue until now, would be difficult to come by. Lastly, and perhaps most importantly, the political context would make the implementation of many of the suggested measures extremely difficult. Most obvious is that the threat of prosecution of individuals, who have the capacity to act as potential spoilers but have so far been kept at bay by integrating them into

\section{Ibid., 54.}

Ibid., 44-53.

Ibid., 49-51. As a possible model for the War Crimes Chamber the study refers to the War Crimes Chamber of the State Court in Bosnia.

Ibid., 50.

Ibid., 28-33, 52, 53.

Ibid., 51.

Ibid., 50, 51. 
the reconstruction process, may destabilize the peace process. Many who could be negatively affected by some of these measures - whether judicial or non-judicial - are in positions of power and have every interest in preventing the implementation of a transitional justice strategy.

Questionable also is whether the local population would be willing to provide the necessary information for truth mechanisms or judicial proceedings. In the face of threats that may come from the affected warlords or other powerful individuals, it is not unlikely that many will remain silent. There is not only a lack of public trust in national judicial institutions to perform the task of national reconciliation as such, ${ }^{333}$ but also a more general lack of trust in state structures, which also arises from the fact that some known perpetrators of human rights violations still hold governmental positions $s^{334}$ and human right abuses are ongoing. ${ }^{335}$ SRSG Brahimi has referred to "the fear that is in the heart of practically every Afghan because there is no rule of law yet in this country". ${ }^{336}$ The report of the AIHRC was thus met with skepticism by some and downright hostility by those who could potentially be affected. ${ }^{337}$ Nonetheless, few would disagree that long-term political stability in Afghanistan can only be achieved if a reconciliation process to resolve past grievances is conducted at some point. ${ }^{338}$ Considering that 69 per cent of the respondents of the survey claimed that either they or a family member had been a victim of human rights violation, ${ }^{339}$ at least symbolic acts ${ }^{340}$ appear in order to build trust among the Afghan population in the political will of state actors to initiate a process of transitional justice. The national consultation was a first step in the right direction and the process should be continued with both financial and political support from the international community. However, choosing a mechanism for national reconciliation which takes into consideration Afghan culture and its history will be vital if the process is to succeed.

333 UNDP Human Development Report 2004, see note 17, 152.

334 AIHRC, see note 325, 11.

335 ICG, Asia Report No. 45, see note 40, 17.

336 SRSG Brahimi in his speech to the closing session of the Constitutional Loya Jirga, quoted in Rubin, et al., see note 195, 10.

337 IWPR, ARR No. 164, Seeking Redress for Past Wrongs, 09-03-05. <http://www.iwpr.net/index.pl?archive/arr/arr_200503_164_1_eng.txt>.

338 UNDP Human Development Report 2004, see note 17, 151.

339 AIHRC, see note 325, 7.

340 AIHRC, see note 325, 44. 


\section{Disarmament, Demobilization and Reintegration (DDR)}

\section{a. Conceptual Issues}

A number of key UN documents have reflected the increasing importance attached to DDR, starting with Boutros-Ghali's 1992 Agenda for Peace ${ }^{341}$ which for the first time accorded institutional recognition of the importance of integrating arms control - mainly mine removal and the demobilization of former combatants - into peace operations. ${ }^{342}$ The Agenda was generally a very optimistic document, reflecting the hope of the international community that the end of the Cold War would herald a return to the effective collective security system originally envisaged in the Charter. The Agenda thus criticizes traditional peace-keeping as born out of the strictures of a polarized world and an incapacitated $\mathrm{UN}$ and argues for complementing it with more active peacemaking and peacebuilding. ${ }^{343}$ In line with the still prevailing Cold War mode of thinking, there is an emphasis on disarmament through ending the supply of weaponry and physically removing small arms and land mines. ${ }^{344}$

The 1995 Supplement to An Agenda for Peace, ${ }^{345}$ written after the

341 Report of the Secretary-General, An Agenda for Peace - Preventive Diplomacy, Peacemaking and Peace-keeping, Doc. A/47/277 - S/24111 of 17 June 1992.

342 For a succinct overview over the development of UN doctrine on this issue see United Nations Association of Great Britain and Northern Ireland, An Agenda for Peace Ten Years On, July 2004, <http://www.globalpolicy.org/ reform/initiatives/ghali/2002/0203ten.htm $>$.

343 Agenda, see note 341, paras 42-45, where he effectively calls for the implementation of the provisions of Arts 42 and 43 UN Charter. The issue of finally activating the Military Staff Committee and some form of standing $\mathrm{UN}$ army was actively discussed at the time. For a good overview of the debate see A. Roberts/ B. Kingsbury, United Nations, Divided World, 1993.

344 Agenda, see note 341, Section VI Post-conflict Peace-building, especially paras 55 and 58.

345 Supplement to An Agenda for Peace: Position Paper of the SecretaryGeneral on the Occasion of the Fiftieth Anniversary of the United Nations, Doc. A/50/60 - S/1995/1 of 3 January 1995; also available at: <http://www.un.org/Docs/SG/agsupp.html> (accessed on 2 May 2005). 
failures of Bosnia and Somalia, ${ }^{346}$ is generally more realistic about the challenges posed by complex emergencies and acknowledges that disarmament is not simply a matter of cutting of supply. Proposing the term "micro-disarmament", ${ }^{347}$ it still betrays its intellectual heritage in the arms control movement of the Cold War, but it addressed at length the difficulty of stemming the flow of small arms and land mines over porous borders, and removing them from within a restive population and in difficult terrain. ${ }^{348}$ Nevertheless, it continued to see the issue as primarily a proliferation issue, not a sociological one, i.e. did not accept that it is the combatants not the arms in themselves that are the problem. This element is explicitly recognized in the 2000 Report of the Panel on United Nations Peace Operations ${ }^{349}$ which states that:

"the disarmament, demobilization and reintegration of former combatants - key to immediate post-conflict stability and reduced likelihood of conflict recurrence - is an area in which peacebuilding makes a direct contribution to public security and law and order. But the basic objective of disarmament, demobilization and reintegration is not met unless all three elements of the program are implemented. Demobilized fighters (who almost never fully disarm) will tend to return to a life of violence if they find no legitimate livelihood, that is, if they are not 'reintegrated' into the local economy". 350

The report goes on to argue that the importance of having an integrated approach to all three aspects of the DDR process should be reflected in the funding structure of peace-keeping operations. ${ }^{351}$ Subsequently, DDR has featured prominently in the 2001 Report on the Prevention of Armed Conflict, ${ }^{352}$ the 2003 Interim Report on the Preven-

346 See in this respect the contributions by K. Oellers-Frahm and C. Philipp, in this Volume.

347 See note 345 , para. 60 .

348 Ibid paras 61-65.

349 Doc. A/55/305-S/2000/809. See also Doc. A/55/502, Report of the Secretary-General on the Implementation of the Report of the Panel on United Nations Peace Operations.

350 Ibid., para. 42, emphasis added.

351 Ibid., paras 42-46, 47 (c).

352 Report of the Secretary-General, Prevention of Armed Conflict, Doc. A/55/985-S/2001/574 of 7 June 2001, paras 83, 93, 102, 127, Recommendation No. 15. In response to which the Security Council adopted 
tion of Armed Conflict ${ }^{353}$ as well as in most post-conflict operations. ${ }^{354}$

\section{b. DDR in the Afghan Context}

As we have noted before, the Afghan settlement was idiosyncratic in many respects, not least with respect to the settlement of the military conflict between the warring factions. The Bonn Agreement did not mark the end of a long political process but rather the beginning of transition. Furthermore, it accompanied rather than ended the decisive military conflict. The Northern Alliance, which was allied with the American-led Coalition against the Taliban government, as well as a host of other armed formations that collaborated in the subsequent fight against remnants of al Qaeda, enjoyed a privileged position in the transition process. These units were not only not subject to demobilization, but continued to receive active military and financial support by the Coalition while remaining outside the purview of the central government. The stipulation of the Bonn Agreement that all armed factions would come under the command and control of the Interim Authority ${ }^{355}$ already fell short of the usual requirement of post-conflict DDR because it did not require actual demobilization but "merely" the reorganization into national armed forces. Even this limited requirement, however, has not been met by many militias allied with the Coalition.

Various other aspects also obstruct the DDR process in Afghanistan. After having been involved in an armed conflict for over two decades, there is a lack of confidence in the state institutions to ensure a secure environment. ${ }^{356}$ In view of the present lack of a viable Afghan security force, ${ }^{357}$ the resurgence of warlords, ${ }^{358}$ the instability of the state, ${ }^{359}$ and

S/RES/1366 (2001) of 30 August 2001, note particularly para. 13 regarding the illicit flow of small arms.

353 Doc. A/58/365 -S/2003/888.

354 For an overview of UN action in this respect see the UN website Preventive Action and Peacemaking, <http://www.un.org/Depts/dpa/prev_dip/ fr_preventive_action.htm>.

355 Section V (1) Bonn Agreement.

356 Özerdem, see note 43, 967.

357 M. Sedra, New Beginning or Return to Arms? The Disarmament, Demobilization E Reintegration Process in Afghanistan, Bonn International Center for Conversion, 2003, 8, <http:www.bglatzer.de/arg/arp/sedra.pdf>

358 M. Sedra, The Cost of Complacency, Afghanistan's Faltering PeaceBuilding Process, Foreign Policy in Focus, March 2003, 1, 
an apparent deterioration of the security situation, ${ }^{360}$ this fear is not surprising. This goes hand in hand with a cultural context in which it is normal to own guns. ${ }^{361}$ Furthermore, while there have been indications of a substantial economic recovery over the last few years, there is an unequal distribution of wealth and the majority of the Afghan population would be classified as poor. ${ }^{362}$ Some combatants will believe that giving up the gun means giving up one's livelihood. In terms of both disarmament and reintegration, the drug trade is a hindrance. It is not only a lucrative option for an ex-combatant, ${ }^{363}$ but the porous borders and the financial potential of poppy trade also provide possibilities for rearmament. ${ }^{364}$

\section{c. International Support for DDR}

In line with the strategic importance attached to DDR in UN doctrine, UNDP and UNAMA have jointly launched Afghanistan's New Beginnings Program (ANBP) ${ }^{365}$ to support the Ministry of Defense in the implementation process. The DDR process in the form of the ANBP, which is mainly being financed by Japan as the lead nation in DDR, was not launched until $2003^{366}$ after several proposals and efforts had failed. ${ }^{367}$ By February 2005 about 70 per cent of the estimated Afghan Military Forces (AMF) personnel were reported to have been dis-

<http://www.fpif.org/pdf/gac/OUS0303afghanrebuild.pdf>; UNDP, Afghanistan National Human Development Report 2004, see note 17, 52.

359 UNDP Human Development Report 2004, see note 17, 52.

360 Rubin, et al., see note 195, 10, 11; M. Sedra/ P. Middlebrook, Afghanistan's Problematic Path to Peace: Lessons in State Building in the Post.-September 11 Era, Foreign Policy in Focus, March 2004, 3, 7, <http://www.fpif.org/ papers/2004afgh-stbuild.html>; UNDP, Afghanistan National Human Development Report 2004, see note 17, 52, 53.

361 Özerdem, see note 43, 967.

362 UNDP Human Development Report 2004, see note 17, 29-36.

363 Rubin, et al., see note 195, 14; ICG, Asia Briefing No. 35, see note 47, 8.

364 Özerdem, see note 43, 967.

365 For information, in particular up to date data on decommissioning figures, see the official website <http://www.undpanbp.org/>.

366 Ibid., 11; Report of the Secretary-General, see note 160, para. 16.

367 Sedra, see note 358, BICC, 4, 5, FPIF, 2; for details see ICG, Asia Report No. 65, Disarmament and Reintegration in Afghanistan, 30 September 2003, 8 and seq. 
armed. ${ }^{368}$ These figures, however, overstate the success of the DDR process because - as we have already indicated earlier - the ANBP's mandate covers only those units recognized as AMF units by the Ministry of Defense, ${ }^{369}$ which leaves out substantial numbers of armed groups. These illegal units ${ }^{370}$ could possibly be strengthened by decommissioned AMF combatants - some of whom continue to enjoy the support of the Coalition - which would further impede the efforts of the central government to extend state authority beyond Kabul. ${ }^{371} \mathrm{Al}-$ though there appear to be plans to launch a new program aimed at disarming these illegal armed groups, a specific strategy has not yet been decided upon. ${ }^{372}$ At the moment these private militias are considered the country's greatest danger. ${ }^{373}$

The initial lack of initiative and effective measures from the international community has not helped the DDR process. ${ }^{374}$ The International Security Assistance Force (ISAF) and the UN did not gain support from the US for the withdrawal of heavy weapons and military forces from Kabul until the end of 2003. ${ }^{375}$ The necessary Presidential decree providing for the cantonment of all AMF heavy weaponry by the Ministry of Defense with the assistance of the ANBP, was not issued until 27 March 2004. ${ }^{376}$ Originally, the cantonment of heavy weaponry had not even been included in the ANBP. In addition, not a single country sent military observers or monitors for the disarmament and demobilization of militia units, and until 2002 the US refused to involve Coalition forces in DDR, thereafter confining their role to a political one. ${ }^{377}$

368 ICG, Asia Briefing No. 35, see note 47, 5.

369 Report of the Secretary-General, see note 160, para. 19.

370 The illegal armed groups are thought to include between 65,000 and 80,000 armed combatants. ICG, Asia Briefing No. 35, see note 47, 11.

371 Ibid., 11.

372 Ibid., 11.

373 UNDP Human Development Report 2004, see note 17, 52.

374 Sedra, FPIF, see note 367, 2; for details, see ICG Asia Report No. 65, see note 367,8 et seq.

375 Rubin, et al., see note 195, 12.

376 ICG, Asia Briefing No. 35, see note 47, 9.

377 Rubin, et al., see note 195, 13. 


\section{d. Critique of the International Effort}

Considering the relative pace of disarmament, a successful nationwide DDR requires the presence of a neutral armed force. ${ }^{378}$ A DDR program cannot be implemented in a security vacuum ${ }^{379}$ where the state or a supporting international force has no authority. Especially in areas with rival factions, each side will only be willing to disarm if there is a neutral (and effective) security force that will protect them until the DDR process has been fully completed by all sides. ${ }^{380}$ ISAF could potentially perform this function, but to do this, its mandate has to be extended even further to allow more significant presence beyond Kabul. ${ }^{381}$

The most important obstacle for DDR originating from the international community, however, is the fact that while efforts are being made to ensure a stable peace-building process, a "war on terror" is still being fought in Afghanistan. In the face of the military operations being conducted in the pursuit of al Qaeda, the assumption that all international actors involved aim for total disarmament of Afghan militias does not hold true. ${ }^{382}$ Immediately after September 11, the Northern Alliance received large amounts of money from the US which was intended to secure allegiance for Operation Enduring Freedom and enable rearmament. ${ }^{383}$ The US-led Coalition has utilized regional warlords and power brokers as proxies in the fight against the Taliban, effectively returning large parts of the country to the status quo before $1996 .{ }^{384}$

In the process, militia leaders have not only frequently managed to subvert DDR with the tacit support of the central government and/or the Coalition, ${ }^{385}$ but they have also been empowered militarily and economically by the US-led Coalition, thereby helping them to resist

378 ICG Asia Report No. 65, see note 367, 23.

379 B.R. Posen, “The Security Dilemma and Ethnic Conflict", Survival 35 (1993), 27 et seq.; Melander, see note 19.

380 B.R. Rubin, Identifying Options and Entry Points for Disarmament, Demobilization, and Reintegration in Afghanistan, Center on International Cooperation, 2003, 6.

381 On ISAF's present mandate, see note 2.

382 Özerdem, see note 43, 967.

383 Sedra, BICC, see note 367, 2.

384 Sedra/ Middlebrook, see note 360, 3, 7.

385 ICG, Asia Briefing No. 35, see note 47 6, 7. 
central government control. ${ }^{386}$ Some of the local and regional commanders whom the US Coalition forces have supplied with weapons to assist in the campaign against al Qaeda have been implicated in past war crimes and have used these arms to equip militias for their own political purposes. ${ }^{387}$ With the "war on terror" being conducted at the same time as a DDR strategy is being implemented, the chances of success for the latter appear to be very bleak.

\section{Conclusion}

From the moment the Taliban regime was ousted by the US-led military campaign, the number of international actors influencing the reconstruction process in Afghanistan has multiplied. Nonetheless, in comparison with many other countries where the UN has played a significant role in the peacemaking and reconstruction process, due to Brahimi's light footprint approach, the Afghan authorities are more actively involved in all aspects. Without doubt, ensuring security will be an absolute prerequisite for the establishment of a functioning democratic state in adherence of the rule of law. This aspect will be decisive for the reconstruction process and is momentarily encumbered by a number of factors.

On the one hand, there is the problem of warlords who control wide areas of Afghanistan outside of Kabul. Thus, there is no state monopoly of power - a problem that is exacerbated by the opposing goals of the US-led Coalition forces still in the country and the NATO-led ISAF. While ISAF is mandated with peace building and ensuring the implementation of the Bonn Agreement, the US-led Coalition forces are fighting a "war on terror" that sporadically requires working with regional warlords, thereby undermining the central government. ${ }^{388}$ The warlords hamper the establishment of security in a number of ways: they obstruct demobilization of their militias, some finance themselves through the narcotics trade, and they dominate processes of conflict

386 ICG Asia Report No. 65, see note 367, 1, 7, 8.

387 ICG, Asia Report No. 45, see note 40, 15.

388 S. Barakat, "Setting the scene for Afghanistan's reconstruction: the challenges and critical dilemmas", Third World Quarterly 23 (2002), 801 et seq. (802); Saikal, see note 205, 50; A.A. Jalali, “Afghanistan in 2002: The Struggle to Win the Peace”, Asian Survey 43 (2003), 174 et seq. (183); Rubin, see note $36,570,571$. 
resolution that prevent the growth of an independent judiciary in their areas.

The Coalition strategy of winning warlords in the fight against terror undermines in several respects the efforts of the international community to support a functioning central government. While Coalition leaders pay lip service to the strategic aim of a strong Afghan state, they allow short-term tactical considerations often to trump this aim. The United Nations' effort in Afghanistan has deliberately concentrated on building Afghan capacity and enabling local governmental and administrative structures to develop. Thus, the strategic vision of the UN and the Coalition might not necessary be at odds, but important divisions exist at the level of tactical implementation.

Despite these difficulties, the UN has tried to avoid some of the pitfalls of earlier missions by insisting on an integrated approach to planning and operational implementation. UNAMA has been given the task of coordinating not only the work of all the other $\mathrm{UN}$ agencies active in the field, but, equally important, of ensuring that the lead nations which have been given the main responsibility for specific activities in the security sector ${ }^{389}$ do so under an integrated strategic vision and with sufficient Afghan input and ownership.

While the role of the UN is thus, of necessity, an important one, UNAMA as its chief representation has made an effort to prevent evolving into a parallel government rivaling the authority of the Afghan administration. Despite the enormous disparities in financial resources, human capital and experience, and operational capacity, UNAMA has generally resisted the temptation ${ }^{390}$ to sidestep the government and simply provide the kind of services that are necessary but which the

389 Japan is responsible for demobilization, Germany for capacity building within the Afghan police force, Italy is to help reconstruct and rehabilitate the justice sector, the US is aiding the establishment of the Afghan National Army, and the United Kingdom is dealing with the counter-narcotics tasks.

390 This fundamental problem of development assistance is ably described by Fukuyama: "The contradiction in donor policy is that outside donors want both to increase the local government's capacity to provide a particular service like irrigation, public health, or primary education, and to actually provide those services to the end user. The latter objective almost always wins out because of the incentives facing the donors themselves. While many donors believe they can work towards both goals simultaneously, in practice the direct provision of services almost always undermines the local government's capacity to provide them once the aid program terminates." Fukuyama, see note 7, 40. 
Afghan civil service is, as yet, unable to make available. It has, by and large, also done a good job in ensuring that bilateral donors and NGOs likewise do not undermine local capacity by creating parallel structures.

Taking into consideration the many negative factors hampering the effort to build local capacity and ownership and to coordinate competing institutional, political and military interests, UNAMA has managed admirably well to nurture Afghan ownership in the reconstruction process. While it is highly likely that major obstacles will continue to beset the reconstruction effort, it is doubtful whether any other approach by the UN would have had the same positive effects that we see now.

Some of the most fundamental institutional prerequisites for the continuation of the reconstruction process and the gradual creation of the rule of law are now in place: most importantly, the adoption of a modern constitution that enjoys widespread legitimacy and which is moderately liberal without alienating the more conservative sections of society, a major fault of earlier projects of constitutional social engineering. Related important steps have been the election of a legitimate government in reasonably free and fair elections, setting a precedent that will hopefully hold. It must, however, be said, that this success story can only be continued if the international community remains willing to provide the necessary political, institutional and financial support. Should the UN withdraw before the country has been stabilized, it is very likely that Afghanistan will fall back into a state of internal conflict, whose ramifications will probably not remain limited to Afghanistan alone. 